Portland State University

PDXScholar

Summer 1985

\title{
Characterization of a new freshwater methanogen, Methanogenium wolfei sp. nov.
}

Theodore B. Moore

Portland State University

Follow this and additional works at: https://pdxscholar.library.pdx.edu/open_access_etds

Part of the Bacteriology Commons, and the Biology Commons Let us know how access to this document benefits you.

\section{Recommended Citation}

Moore, Theodore B., "Characterization of a new freshwater methanogen, Methanogenium wolfei sp. nov." (1985). Dissertations and Theses. Paper 3537.

https://doi.org/10.15760/etd.5421

This Thesis is brought to you for free and open access. It has been accepted for inclusion in Dissertations and Theses by an authorized administrator of PDXScholar. Please contact us if we can make this document more accessible: pdxscholar@pdx.edu. 
AN ABSTRACT OF THE THESIS OF Theodore B. Moore for the Master of Science in Biology presented July 23, 1985.

Title: Characterization of a new freshwater methanogen,

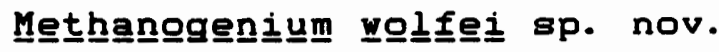

APPROVED BY THE MEMBERS OF THE THESIS COMMITTEE:

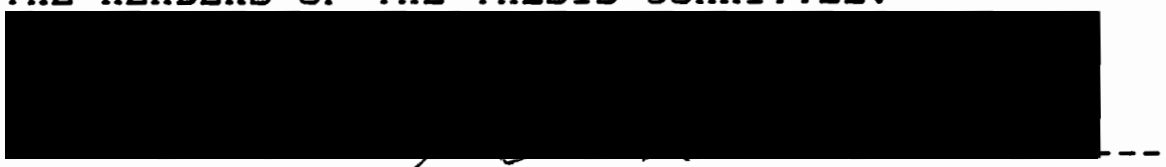

L. Dudley Eirich, Chairman

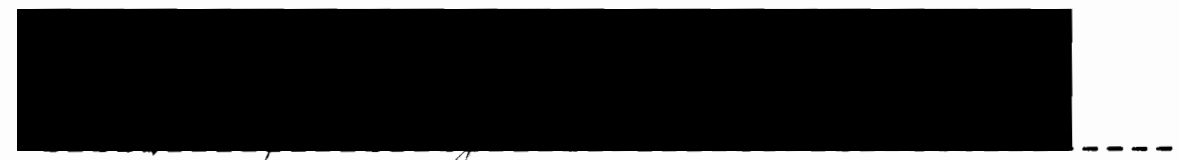

Mary L. Taylor

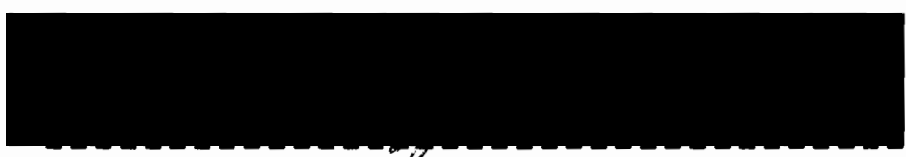

B. E. Lippert

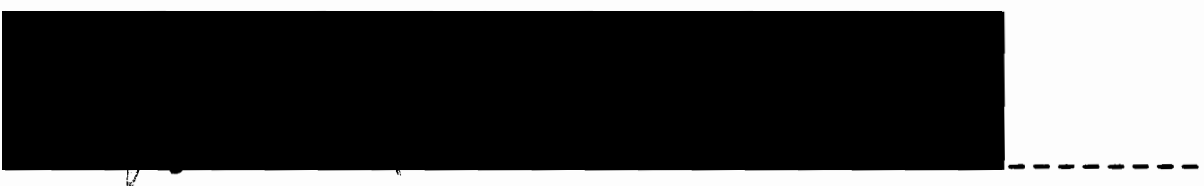

Norman C. Rose

Abstract.

A recently isolated freshwater methhanogogeniuㅡㅛ species,

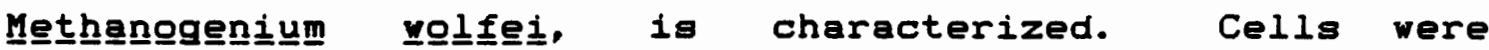
irregular cocci, measuring 1.5 to 2.0 micrometers in diameter. No motility was observed, but 1 to 2 flagella per cell vere observed after staining with Gray's Flagella 
Stain. Colonies formed by this species vere small, shiny, and green-brown in color. Formate or hydrogen plus carbon dioxide served as substrates for growth. The optimal temperature for growth was found to be 45 degrees centigrade with minimal growth below 30 degrees centigrade and above 55 degrees centigrade. The optimal pH for growth was determined to be 6.8. Optimal growth was obtained vithin a 0.0 to $0.2 M$ range of added sodium chloride. Acetate and arginine were required for growth. DNA base composition was 61.1 mol\% $G+C$. The presence of coenzyme F-420 at a concentration of $134 \mathrm{mg} / \mathrm{kg}$ cells (wet weight) was determined in cell extracts. The enzyme NADP reductase was found to be present and was partially characterized. 


\author{
CHARACTERIZATION OF A NEW \\ FRESHWATER METHANOGEN,

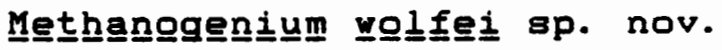

by

THEODORE B. MOORE
A thesis submitted in partial fulfillment of the requirements for the degree of

\author{
MASTER OF SCIENCE \\ in \\ BIOLOGY
}


TO THE OFFICE OF GRADUATE STUDIES AND RESEARCH:

The members of the committee approve the thesis of Theodore B. Moore presented July 23, 1985.

L. Dudley Eirich, Chairman
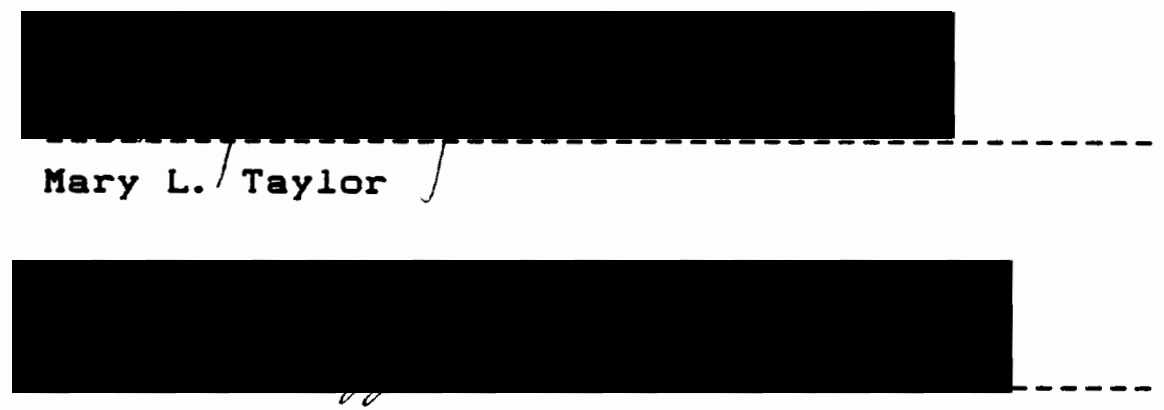

B. E. Lippert

Norman C. Rose

\section{APPROVED:}

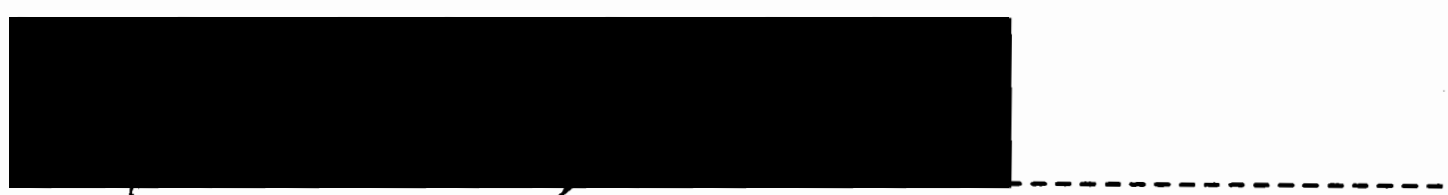

Herman Taylor, Head Department of Biology

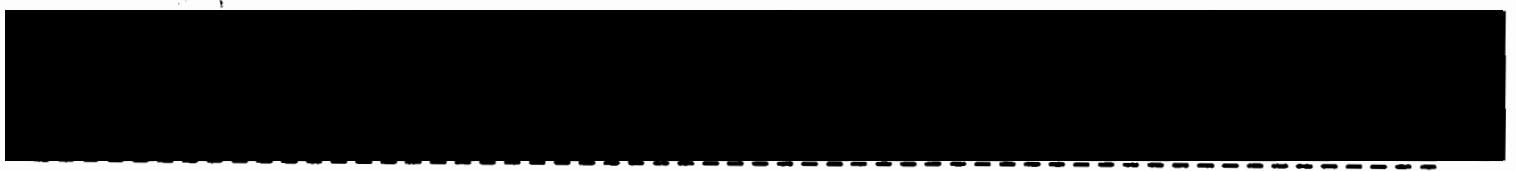

Jim F. Heath, Dean of Graduate Studies and Research 


\section{ACKNOWLEDGEMENTS}

I wish to thank Dr. L. Dudley Eirich for his patient guidance and encouragement, without which this work would not have been possible.

Appreciation is also due to Dr. Lester Newman for both technical advice and encouragement.

I thank Hoang Chi Duong-Tran for technical assistance in the $l a b$ and for losing so graciously time after time on the racquetball court. Special thanks are also due to Quang Duong-Tran and Chuong Nguyen for their technical assistance and instruction in computer processing of data.

I also thank my comrade and fellow conspirator in graduate school, Terry Coons, for her positive attitude, being a fantastic study partner, and a terrific friend. 
TABLE OF CONTENTS

PAGE

ACKNOWLEDGEMENTS...........................

LIST OF TABLES.......................... vi

LIST OF FIGURES.......................... vii

INTRODUCTION........................... 1

A REVIEW OF KNOWN METHANOGENIC BACTERIA............. 5

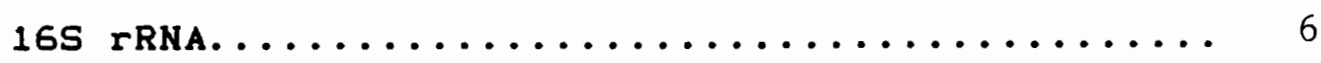

F-420-dependent NADP Reductases.............. 9

Classification and Description.............. 15

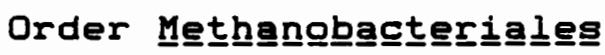

Order Methangococçale日

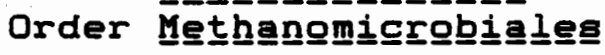

MATERIALS AND METHODS........................ 22

Culture Methods....................... 22

Photography.......................... 25

DNA Isolation and Base Composition Analaysis.... 25

Preparation of Crude Extract.............. 28

Assay Procedure for NADP Reductase............. 29

Purification and Preparation of Reduced F-420... 30

Standard Asmays for Growth and Methane

Production.......................... 30

RESULTS................................ 31

Enrichment and Isolation................. 31

Microscopic Examination ................. 32 
Optimal Growth Conditions................. 32

Organic Growth Requirements................. 41

Growth Substrates....................... 48

DNA Base Composition..................... 48

Presence of an F-420 -dependent NADP Reductase and Determination of $F-420$ content............ 48

DISCUSSION. 


\section{LIST OF TABLES}

TABLE

PAGE

I Comparison of the Properties of known

NADP Reductases.................... 17

I I Compositions of Standard Media.............. 24

II Growth Requirements of Methananggeniuㅡ wollfei.... 45

IV A Comparison of the Properties of the known species of Methangogeniu…............ 


\section{LIST OF FIGURES}

FIGURE

PAGE

1. Taxonomic Treatment for the Methanogenic

bacteria based on 165 rRNA Comparative

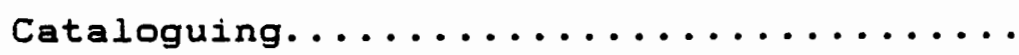

2. An Updated Scheme of the Methanogenic

Bacteria........................... 11

3. The Structure of Coenzyme F-420........... 14

4. A Typical Regular to Irregular Cocci of

M.

5. Gray's Flagella Stain of M._wolffe…...... 36

6. Effect of sodium chloride on the growth of

M.

7. Optimal Temperature for Growth of M._wolfe… 40

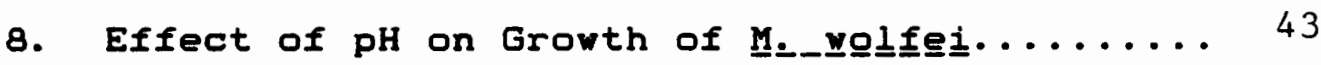

9. Scheme for Determination of Amino Acid

Requirements...................... 47 


\section{INTRODUCTION}

The atrictly anaerobic methanogenic bacteria are a morphologically diverse group of organiams, consisting of long and short rods, cocci, spirilla and chains or aggregates of these basic forms. They are unique among prokaryotes, having in common the metabolic capability of producing methane gas. Although the process by which methanogens reduce carbon dioxide to methane is not entirely understood, there has been much information that has added clarity concerning the process. The use of hydrogen by methanogens as the sole electron donor for methanogenesis and growth is nearly universal. Hydrogen is the substrate for the reduction of carbon dioxide to methane. Some species are capable of using formate as a carbon and energy source, while others can use methanol, methylamines, and acetate for growth and methane production. The methanogens are also distinct from other prokaryotea in cell wall etructure. The cell walla of known methanogens lack $\mathrm{N}$-acetyl muramic acid and do not utilize D-amino acids. The cell membranes of methanogens differ from other prokaryotea becauge they contain phytanyl glycerol ethers. Studies comparing the 165 and 185 rRNA of prokaryotes and eukaryotes, respectively, have ghown the methanogens to be as distantly related phylogenetically to 
eubacteria as they are to eukaryotes. Woese et al. $(1,2)$ have proposed that the methanogens be placed in a separate kingdom named the Archaebacteria.

\section{HABITATS}

The methanogens are found in a variety of places where organic matter undergoes anaerobic degradation ( 3 ). Areas such as anaerobic sewage digestors and landfills commonly contain methanogens. Methanogenic bacteria are found in a variety of aquatic environments including the sediments of lakes, ponds, swamps, deep ocean trenches, and hot springs. They are most obvious in places where plants die and decompose under water, where the water acts as a blanket to help keep out oxygen and thus aid in the growth of anaerobic organisms. Living organisms have also been found to harbor methanogens. These include the intestinal tract of man, the heart rood of trees (4), and the rumen of cattle (where they may form 100 to 500 liters of methane daily per cow) (5). In these environments, the methanogens facilitate the terminal atep in the anaerobic degradation of organic material to methane and carbon dioxide.

\section{THE FLOW OF CARBON TO METHANE}

In the process of anaerobic fermentation, bacteria convert organic matter to methane and carbon dioxide with only a emall portion of the free energy going to an increase in microbial cells (6). Ninety percent of the 
energy of the substrate is retained in the form of methane.

There are basically three major steps involved in the fermentation process of proteins, carbohydrates and lipids. The first major step involves the breakdown of these major building blocks to their subunits. These subunits include amino acids, methanol, sugars, glycerol and fatty acids. The subunits are then in turn further broken down. The sugers are broken down via mixed acid fermentation to a variety of acids. The major end product of this second step is acetate. In the last step of the fermentation process, acetate, hydrogen and carbon dioxide are converted to methane. Hydrogen is readily used up during the process of methanogenesis, thus driving the whole fermentation process towards methane production. This provides for a maximizing of the recovery of energy in the form of methane.

There are a number of organisms involved in the overall process of the degradation of organic matter to methane. The complex polymers are broken down to soluble products by enzymes such as cellulases, amylases and proteases that are produced by fermentative bacteria. These products are usually in turn fermented primarily to short chain fatty acida, hydrogen and carbon dioxide. The fatty acids are then metabolized to acetate by the acetogenic bacteria which also give off hydrogen as a by product of their metabolism. The combined effect of these first two groups of bacteria is the conversion of the 
polymeric substrate to acetate, hydrogen and carbon dioxide. The hydrogen and carbon dioxide can be either converted to methane by methanogens, or to acetate by the acetogenic bacteria. Aceticlastic methanogens can split acetate to carbon dioxide and methane. About two-thirds of the methane produced comes from acetate with the remainder coming from the reduction of carbon dioxide. There are only two methanogenic genera that are known to grow by

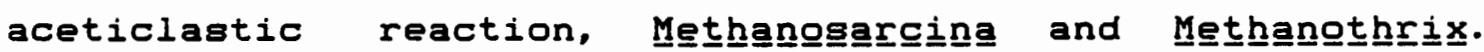
Methhanogsarcina is one of the most versatile of methanogen genera known, being able to utilize hydrogen and carbon dioxide, methanol, methylamines and acetate as substrates for growth.

Aceticlastic and carbon dioxide reducing methanogens have been found to play an important role in the terminal step of interspecies hydrogen ion transfer. As an example, it has been found that in a bioreactor that produces one liter of methane per liter of bioreactor volume per day in which the partial pressure of hydrogen is 0.0001 atmospheres, there is a turnover of hydrogen every 15 seconds. The removal of hydrogen at this rate is of extreme importance. If hydrogen begins to build up, the following acenario could be expected to take place. The high levels of hydrogen would cause a shift away from the generation of acetate from aromatics and fatty acids. There would be a lowering of $\mathrm{pH}$ and eventually failure of the anaerobic digestor $(7,8,9)$. 


\section{A REVIEW OF KNOWN METHANOGENIC BACTERIA}

Noticing the release of combustible air from decaying organic matter on the bottom of lakes and bogs, the famous Italian physicist Volta made documentation of this phenomenon in 1776. This discovery led to further discoveries that established the source of methane production to be microbial (3). H. A. Barker, in 1956, cited this unique property of methane production as the unifying characteristic of a group of bacteria he called

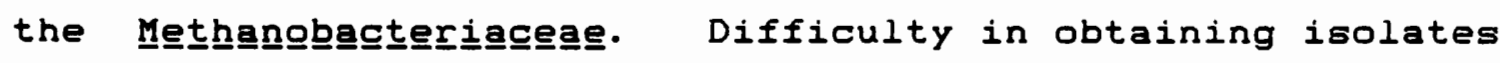
in pure culture made classification within this group quite difficult and often times ambiguous. At the time of Barker's 1956 review of the methanogens, only three species were isolated (10). In 1957, Smith and Hungate developed a modification (11) of Hungate's anaerobic roll tube method, and used this modification to successfully isolate

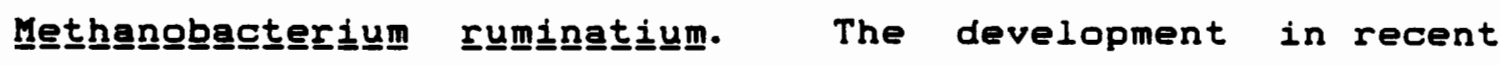
years of improved anaerobic techniques $(12,13,14)$ has facilitated the process of isolation and identification of methanogenic bacteria. In the last five years alone, the number of isolated species has increased from 13 to over 30. The number of genera has increased from 7 to at least 12. 
on a variety of parameters. The criteria for assigning an isolate species status is fairly vague and is occasionally made on the basis of only one simple parameter. An example

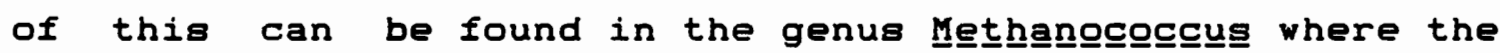

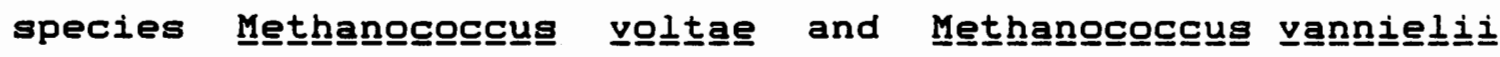
are known only to differ in their requirements for sodium chloride in the media. Among the parameters that are used are such traditional characteristics as morphology, gram reaction and physiological properties. Also useful are molecular qualities such as cell wall and lipid composition, moles percent $G+C$, growth requirements and comparison of 165 rRNA oligonucleotide sequences.

\section{S rRNA}

The comparison of 165 rRNA as a genetic taxonomic tool has greatly facilitated the taxonomic classification of methanogens. First used by Fox (15), it was applied to 10 methanogens. Fox found they fell into two distinct groups. Later, Balch (3) incorporated data from seven other methanogens and came up with a classification scheme based on both 16S rRNA comparison of 165 rRNA oligonucleotide gequences, which are formed after ribonuclease $T 1$ digestion (3), and known morphological and physiological characteristics (see Figure 1). An association coefficient was determined when comparing 165 rRNA of different species. This association coefficient. or $S(A B)=2 N(A B) /(N(A)+N(B)) . \quad N(A B)$ repregents the number of 
FIIGURE__.

TAXONOMIC TREATMENT FOR THE METHANOGENIC

BACTERIA BASED ON 165 TRNA COMPARASION CATALOGUING. 


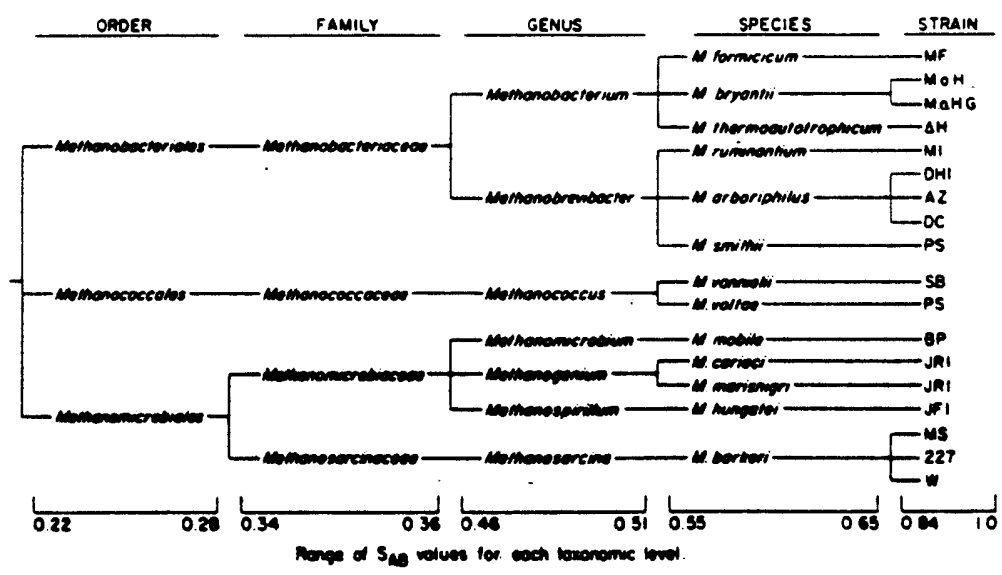

Figure 1 
oligonucleotides common to the catalogues of two organisms, organism $A$ and organism $B$. $N(A)$ and $N(B)$ represent the total number of oligonucleotides, present in hexamers or larger, in the catalogue of organiam $A$ and organism $B$, respectively. $S(A B)$ values can range between 0.00 to 1.00 with the greater value indicating the greater homology. Typically, S(AB) values for strains of the same species range from 0.84 to 1.00 . Members of the same genus rould have $S(A B)$ values greater than 0.45 and members of the same order, greater than 0.34 .

F-420-DEPENDENT NADP REDUCTASES

Since the time of Balch's classification, the number of methanogenic isolates has increased dramatically. As the number of loolates have increased, so also has the need to develop more definitive taxonomic tools for classification. Since comparative genetic techniques have revealed great genetic variability among the methanogena, it is not unreasonable to consider that biochemical and physiological variability also exist. This indeed appears to be the case. Variations in the concentration and structure (16) of the coenzyme F-420 have been digcovered. Variations in the autotrophic biosynthesis of amino acids have been discovered $(17,18,19)$. Variation in the structure of F-420-dependent NADP reductases in methanogens have been demonstrated (20). Eirich (20) has suggeated the posaible aignificance of this variation in use as a taxonomic tool. 
FIIGURE__2.

AN UPDATED SCHEME OF THE METHANOGENIC

BACTERIA. 


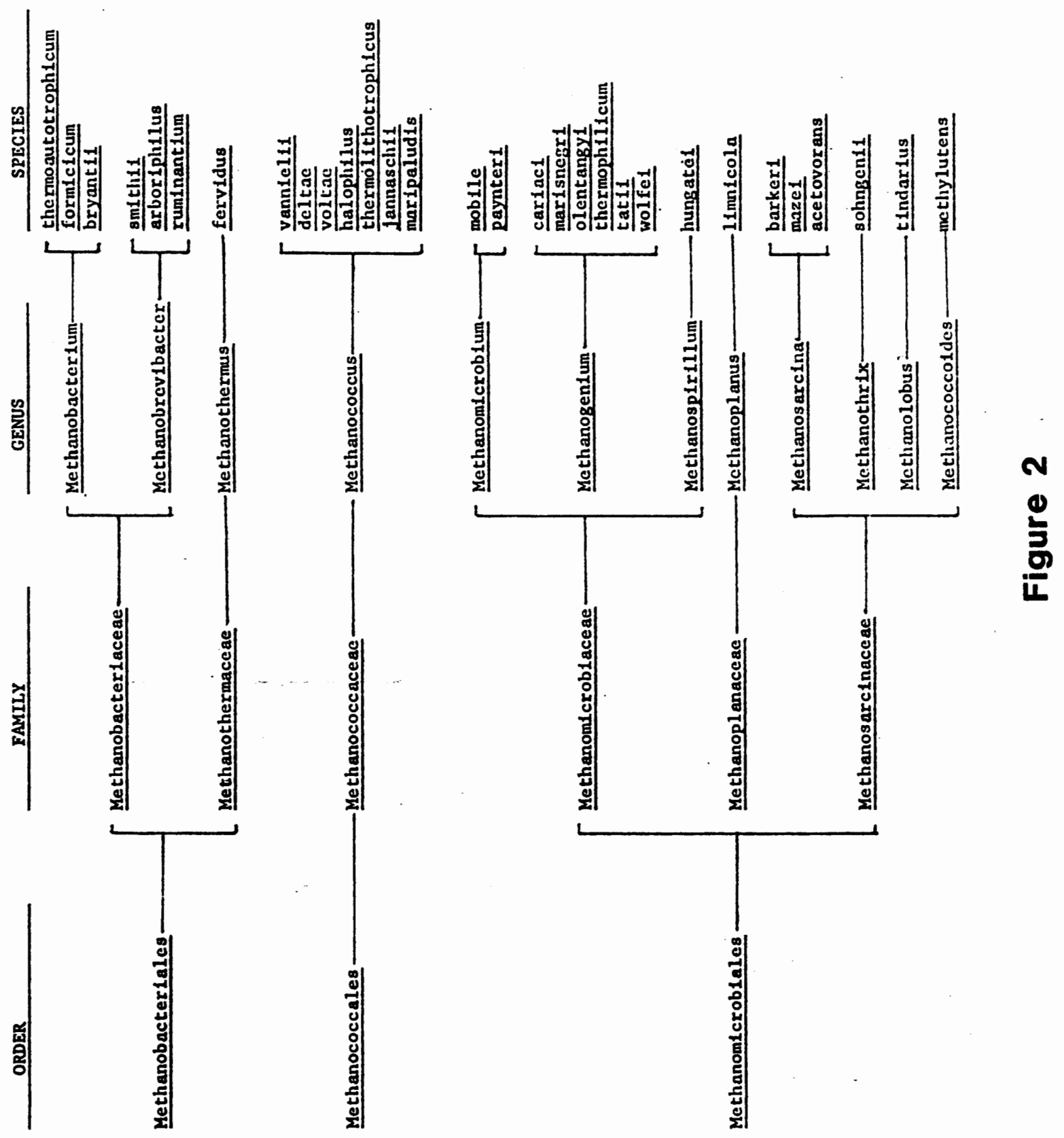


The fluorescent. compound, F-420, was first purified and characterized by Cheeseman et al. in 1972 (21). The structure for F-420 has been elucidated by Eirich et al. (22) and can be seen in Figure 3. F-420 is a yellow compound with a maximum absorbance at $420 \mathrm{~nm}$. F-420 differs from a typical flavin in many respects. There are no methyl groups at the 7-and 8-positions with the 8position being filled by a hydroxyl group. There is a $N-$ (N-L-lactyl-L-glutamyl) $\gamma$-L-glutamic acid moiety connected via a phosphodiester linkage. The most important difference is that there is a carbon rather than a nitrogen at the 5-position. This enables the coenzyme to act more like a pyridine nucleotide than a flavin, not forming a stable free radical, and thus being thermodynamically required to transfer two electrons rather than one. F-420 has been discovered in at least ten methanogen species being in the game form except for one unusual type found in M.--barkeeㅛ․ This form appears to be a polyglutamyl derivative of the more dominant form.

In 1975, Tzeng et al. (23) saw evidence in

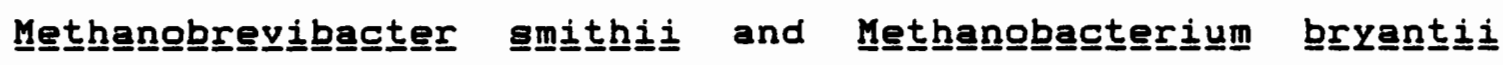
for the presence of an F-420-dependent nicotinamide adenine dinucleotide phosphate (NADP)- linked hydrogenase system. FMN, FAD, methyl viologen and F-420 were all found to be reduced readily by the hydrogenase, but NADP was only reduced in the presence of F-420 or methyl viologen. An F-420-dependent formate hydrogenlyase system in which 
FIGURE_-3.

THE STRUCTURE OF THE COENZYME F-420. 


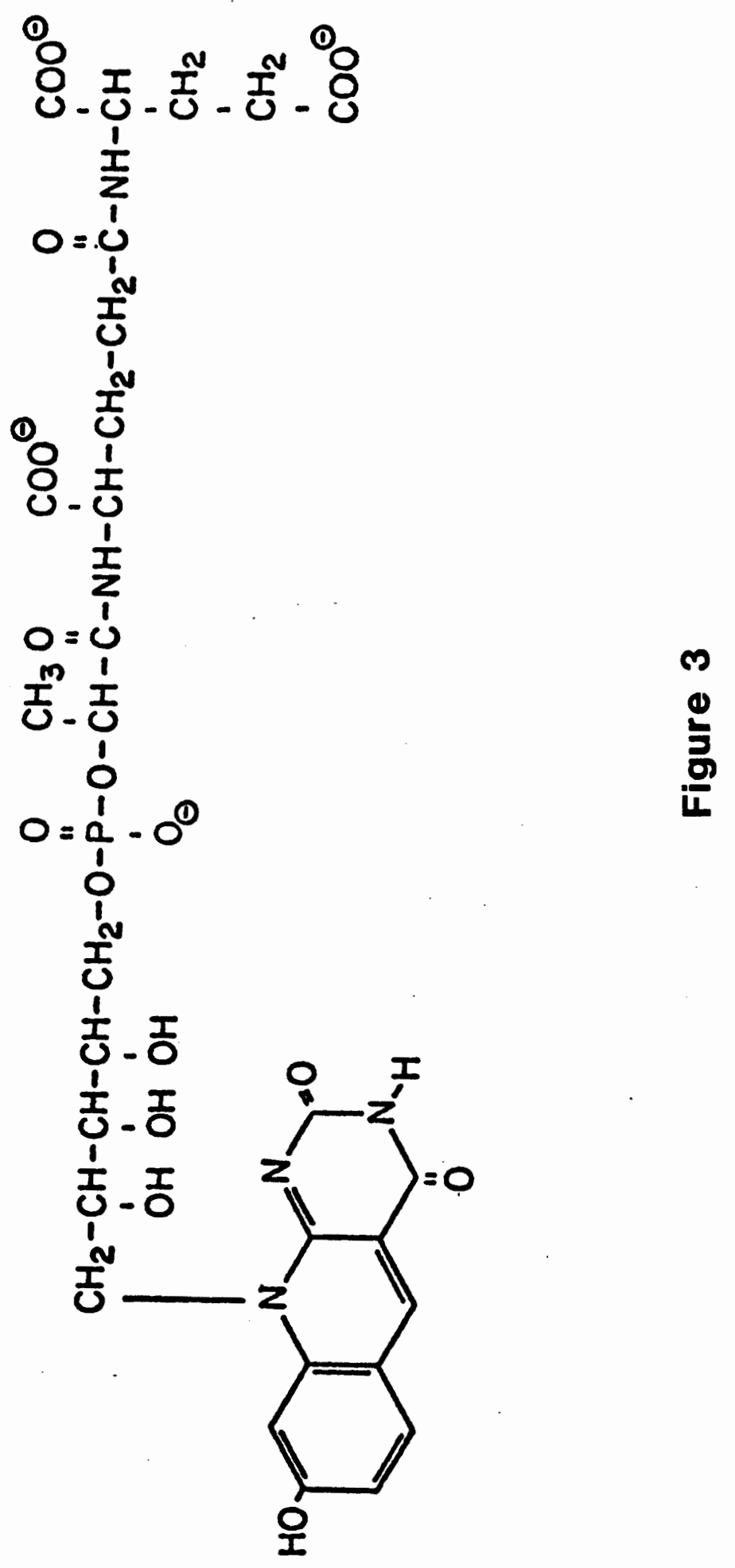


electrons that were generated from formate were transferred by a formate dehydrogenase to F-420 was reported by Tzeng et al. Reduced F-420 could in turn be used as a substrate for the hydrogenase, giving off hydrogen. It was found that the formate dehydrogenase reduced FMN and FAD, but gave off no hydrogen. Rather, electrons from the reduced F-420 were transferred to NADP via an F-420-dependent NADP reductage. NADPH probably supplies a majority of the reducing potential needed to reduce carbon dioxide and implement it into cell carbon $(18,19)$, although the extent of its role is not entirely known.

As the purification and characterization of F-420-dependent NADP reductases have been carried out in various species, significant differences can be seen in a variety of properties such as $\mathrm{Km}$, temperature optimum, $\mathrm{pH}$ optimum. and molecular weight (see TABLE I). A number of major differences can be seen in TABLE I between the NADP reductases isolated from various species. Most significant are those differences in kinetic values, temperature optima and molecular weight. Eirich has proposed that these differences in the properties of NADP reductaseg may reflect phylogenetic differences and thus be useful as an added tool to the taxonomiat.

\section{CLASSIFICATION AND DESCRIPTION}

At this present time, over thirty species of 
TAㅡ트트_I

A COMPARISON OF THE PROPERTIES OF KNOWN NADP REDUCTASES. 


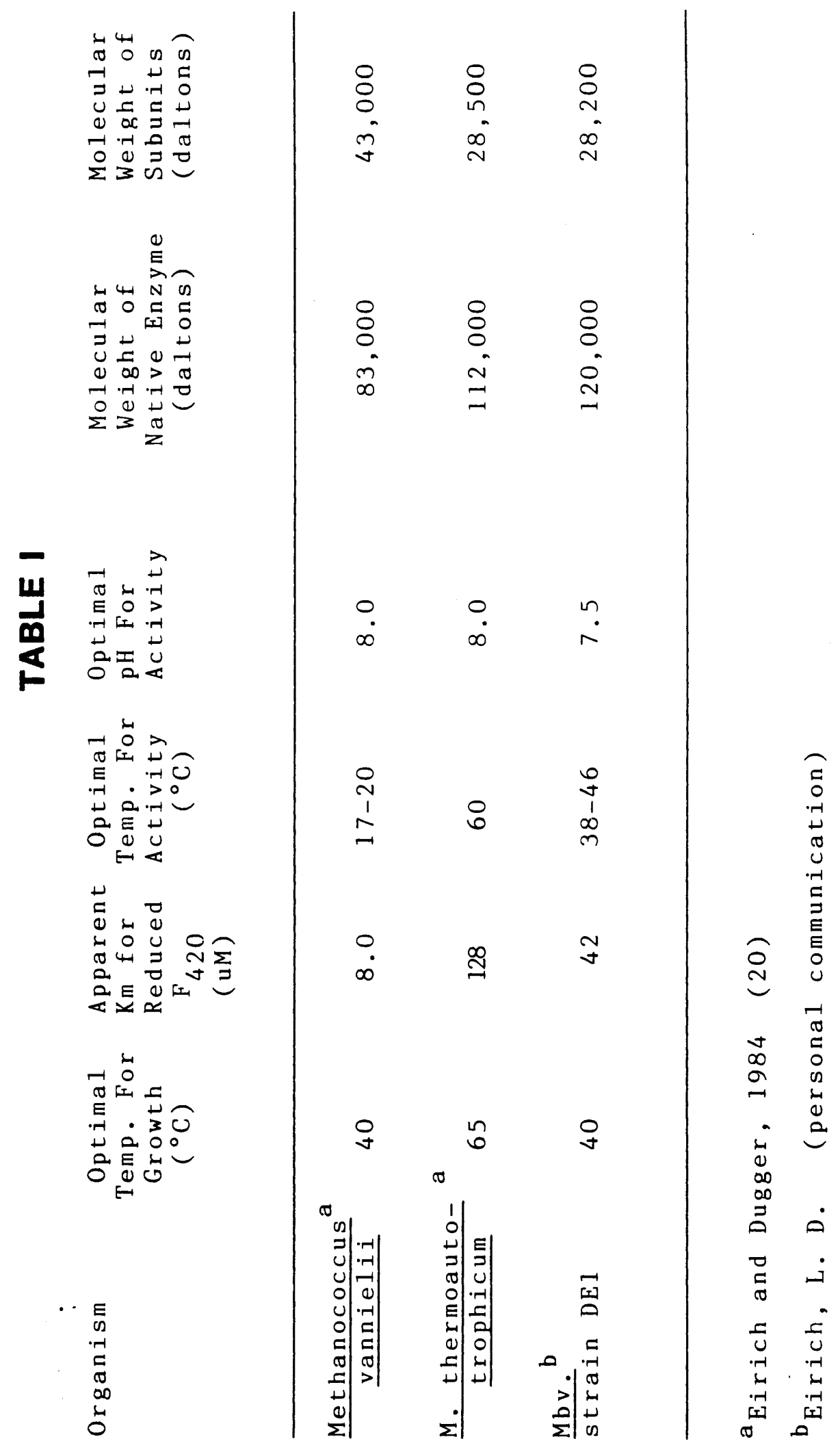


methanogens are known with new isolates being reported at almost a monthly rate. Twelve genera have been defined. These belong to six families and three orders (see Figure 2).

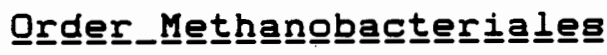

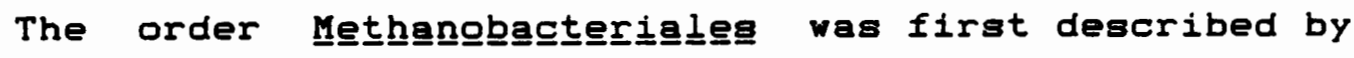
Balch and Wolfe (3). Cells in this order are short, lancet-shaped cocci to long, filamentous rods. Although some strains are variable in their gram stain, most are gram positive. Upon examination of ultra thin sections using transmission electron microscopy, walls appear to be typically gram positive. Cell walls do not contain muramic acid, however, but rather pseudomurein is the major peptidoglycan component. Lipid components are composed primarily of ether-linked polyisoprenoid chain lipids. All members of this order are very strict anaerobes. They obtain energy for growth by oxidizing hydrogen and sometimes formate or carbon monoxide, reducing carbon dioxide to methane. Both coenzyme $M$ and coenzyme F-420 have been demonstrated to be present in cells of this order. They do not utilize carbohydrates, polypeptides or other organic substrates as an energy source other than formate or carbon monoxide. They are found in a variety of anaerobic environments including the sediments of aquatic systems, soil, anaerobic sewage sludge digestiors and the gastrointestinal system of living animals. There are at this time two families that belong to this order. The 


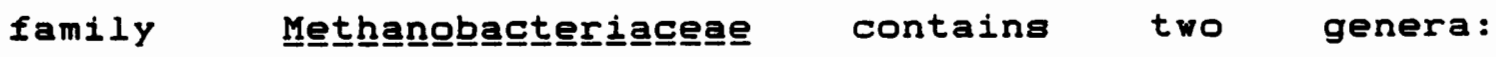

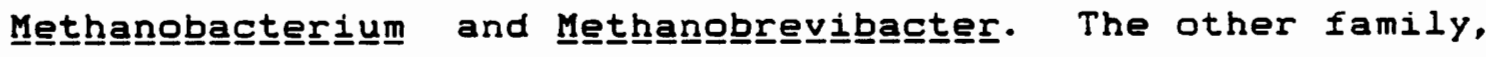

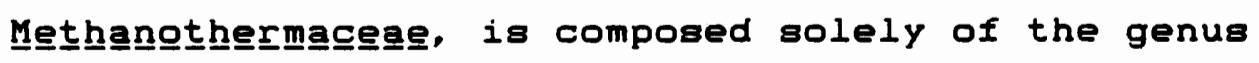

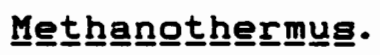

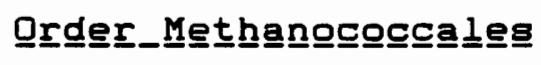

The order Methnanonocococaalege contains only one family,

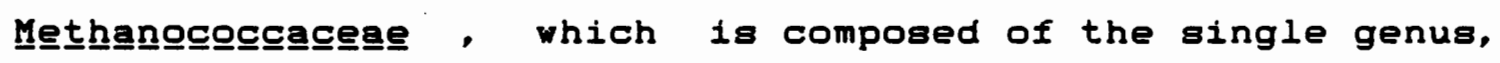

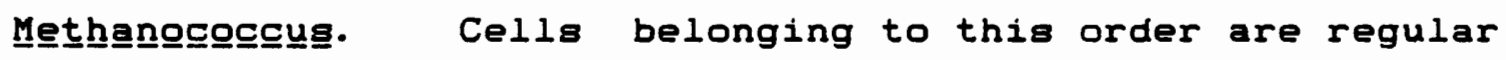
to irregular cocci ranging from 1.0 to 5.0 micrometers in diameter. Cells are very fragile with a negative gram reaction given by the single layer of protein subunits that surround the plasma membrane. Neither muramic acid or pseudomurein can be detected. The major lipid components are ether-linked polyisoprenoid chain lipids. They are very strict anaerobes that oxidize hydrogen or formate, reducing carbon dioxide to methane in order to obtain energy for growth. Both coenzyme $M$ and coenzyme $F-420$ have been shown to be present in cells belonging to this order. They do not use carbohydrates, polypeptides or any other organic material other than formate as an energy source. They are videly distributed in anaerobic habitats and especially in the sediments of aquatic environments.

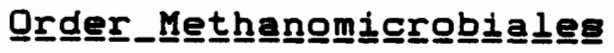

The order Methannomicr three orders. Cells range in morphology from cocci to rods. There are both motile and non-motile species that 
belong to this order. There are both gram negative and gram positive cells. This variability is due to the large range of cell wall structures. None of these contain muramic acid. Lipid components are primarily ether-linked polyisoprenoid chain lipids. Both coenzyme $M$ and coenzyme F-420 have been demonstrated to be present in cells. Members of this order are found in large number of anaerobic habitats such as anaerobic sewage sludge digestor, the gastrointestinal tract of living animals and the sediments of both marine and freshwater environments.

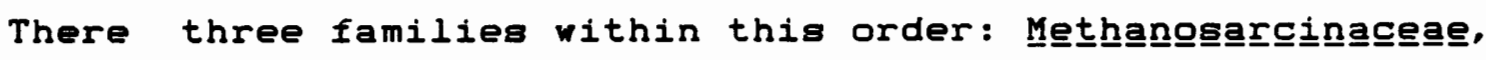

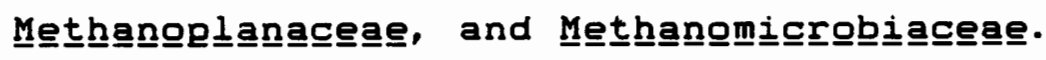

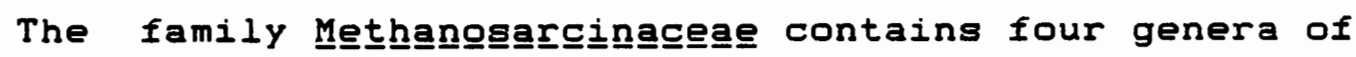
great diversity. Cells are large, spherical to rod-shaped and gram positive. The cocci range in size from 1.5 to 2.5 micrometers in diameter and they are often found in clumps due to the fact that the plane of cellular division is not always perpendicular. Cells are mesophiles to

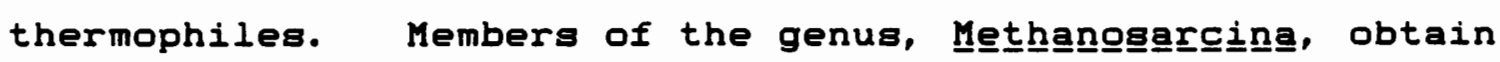
energy for growth by oxidation of hydrogen with the reduction of carbon dioxide to methane or by the metabolism of methanol, methylamine, and acetate with the formation of methane and carbon dioxide as end products. The cell wall

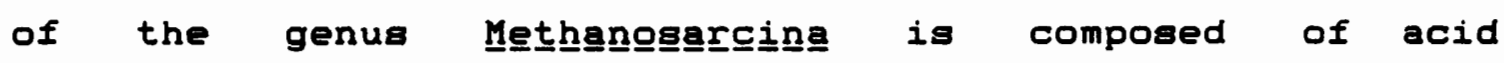
heteropylysaccharide (24) and is typically very thick (500 $\mathrm{nm})$. The sole member of the genus Mẹthangnoncogcocogidge日g,

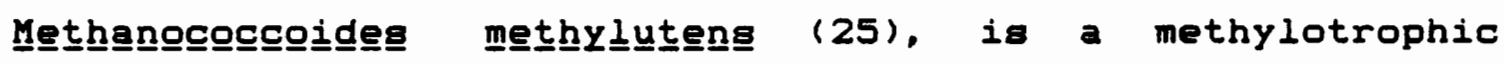




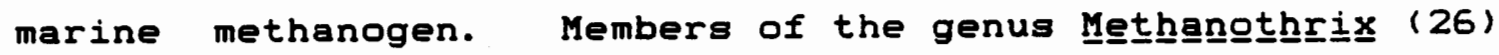
are acetotrophic and do not oxidize hydrogen. The genus

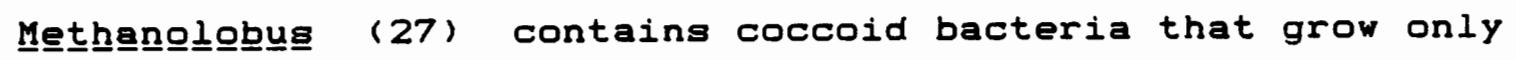
on methanol and methylamines.

The family Methanangoglanagacege (28) contains only one

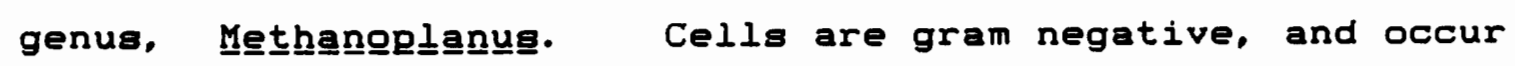
as thin plates with sharp edges, with a hexagonal surface pattern. These plates are 0.07-0.30 micrometers thick, 1.6-2.8 micrometers long, and 1.5 micrometers wide. Cells give a negative Gram reaction. Cells oxidize hydrogen or formate as the sole energy source for growth and methane production.

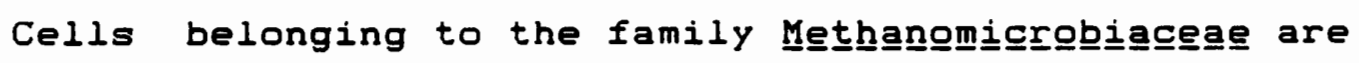
Gram negative. They range in shape from cocci to slightly curved rods. They oxidize hydrogen or formate as the sole energy source for growth and methane production. There are

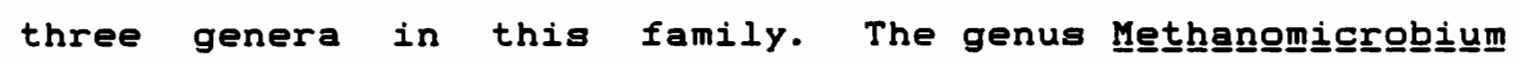
contains cells that are short, straight to slightly curved rods that have rounded ends (29). Only hydrogen serves as a substrate for growth and methane production. The genus

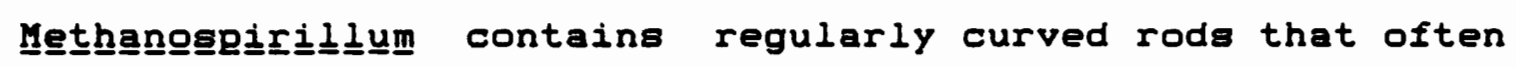
form long spiral filaments. Both hydrogen and formate are utilized for growth and methane production ( 30 ). The genus Methhanggengium (31) contains cells that are irregular cocci ranging from 0.5 to 2.5 micrometers in diameter. Both hydrogen and formate can be used as substrates for most species in this genus which ranges from 52 to $61 \mathrm{~mol} G \mathrm{G}+\mathrm{C}$. 


\section{MATERIALS AND METHODS}

\section{CULTURE METHODS}

The organism was cultured according to the technique of Balch and Wolfe (14). The standard medium for isolation and growth was the complex medium 1 of Balch et al. (3) as shown in TABLE II, modified by the substitution of Tryptone for Trypticase. Minimal medium 2 of Balch et al. (3) as shown in TABLE II was employed for the determination of growth requirements. Media was initially prepared without the addition of the reducing agents, sodium sulfide and cysteine. The media $(20 \mathrm{ml})$ was added to $100 \mathrm{ml}$ serum bottles aerobically. The bottles were then stoppered with rubber stoppers, sealed with aluminum crimp seals and evacuated. Autoclaving of the media was carried out at 121 degrees centigrade for 20 minutes. The serum bottles were then pressurized to 250 kPa with hydrogen:carbon dioxide (80:20 v/v). Resazurin was added to the media as an oxidization indicator, being colorless when reduced and pink when oxidized. The serum bottles were incubated on their sides in order to facilitate diffusion of the gaseous substrate into the media. 
TABㅡ느드모.

COMPOSITIONS OF STANDARD MEDIA USED

FOR THE CULTURING OF METHANOGENIC

BACTERIA. 


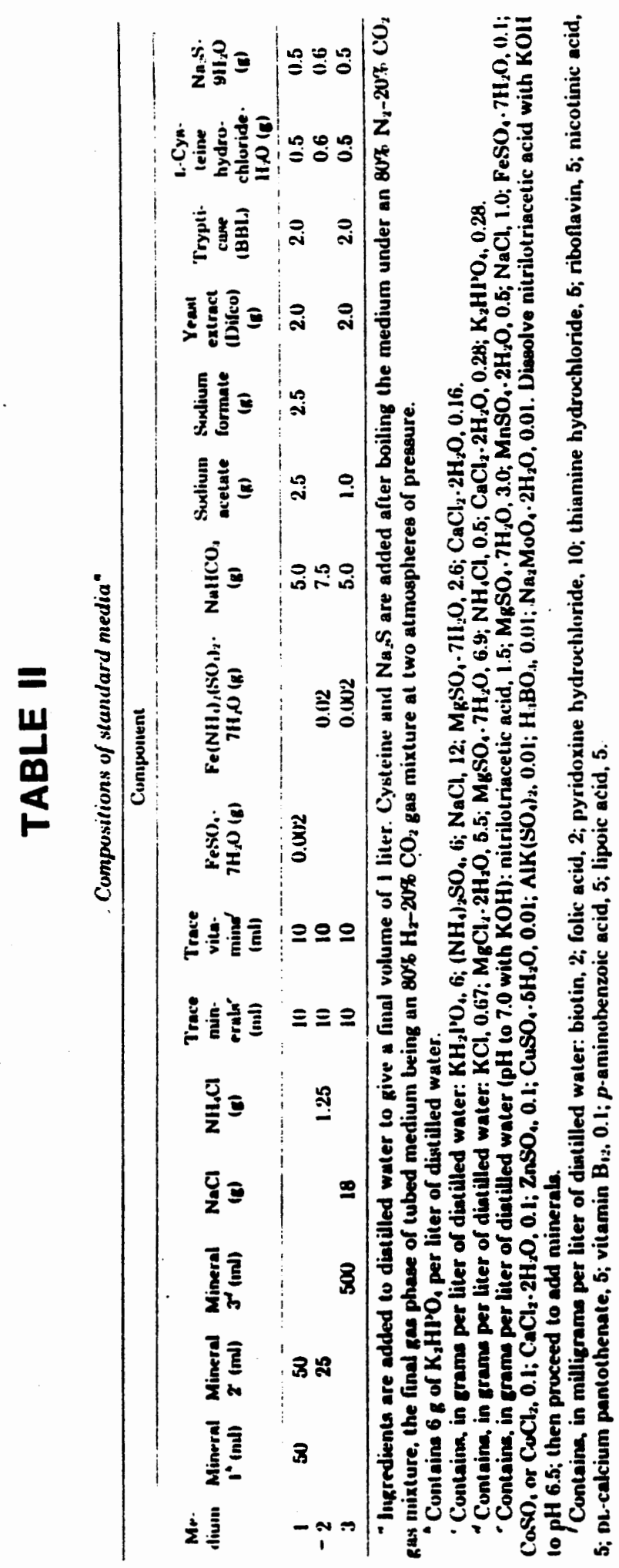




\section{PHOTOGRAPHY}

Photomicrographs were made with a Carl Zeiss Universal Microscope. Flagella were stained with Gray's flagella stain (32). The flagella gtain was composed of two solutions: solution $A$ and solution B. Solution A is composed of $2 \mathrm{ml}$ of tannic acid ( $20 \%$ [wt/vol] aqueous), $5 \mathrm{ml}$ of potassium alum, $2 \mathrm{ml}$ of saturated aqueous mercuric chloride, and $0.4 \mathrm{ml}$ basic fuchsin (3\%[wt/vol] in $95 \%$ [wt/vol] ethanol). Solution B is composed of Ziehl's carbolfuchsin. Organisms in fluid medium were centrifuged to free the specimen from medium constituents, washed, and recentrifuged. Resuspension of the pellet was carried out. gently with aqueous formalin. A loopful of this suspension was allowed to run down a tilted glass slide and was air dried. The slide was placed in solution A for approximately 6 minutes and then washed with distilled water. Blotting paper was placed over the slide and it was flooded with solution $B$ for 3 minutes. The blotting paper was then removed and the slide was washed with distilled water and air dried.

\section{DNA ISOLATION AND BASE COMPOSITION ANALYSIS}

DNA was purified by the method of Saito and Miura (33). This method prepares bacterial DNA by the use of phenol, $\mathrm{pH}$ 9, and RNases. Treatment with phenol is considered to be one of the most effective methods for the removal of proteins. The use of a neutral or acidic buffer 
(pH 5-7) favors the extraction of RNA in the aqueous phase. The use of an alkaline buffer ( $\mathrm{pH} 9$ ) in phenol treatment facilitates the extraction of DNA into the aqueous phase with only little contamination from the RNA. The use of two ribonuclueases, simultaneously, further purifies the DNA by eliminating RNA contamination. The following reagents were prepared for the extraction and purification of the DNA:

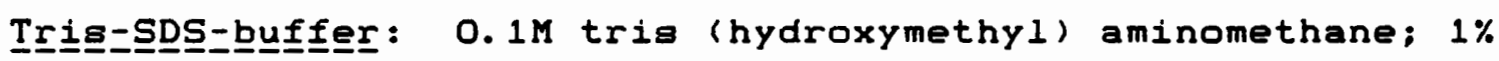
sodium dodecyl sulfate, $0.1 \mathrm{M} \mathrm{NaCl}$. Adjust $\mathrm{pH}$ to 9.0 with concentrated HCl.

Phenenoll=buufㅌㅌㅗ: Phenol (top grade) was saturated with the Tris-SDS-buffer at 0 degrees centigrade. This gives $80 \%$ phenol (weight percent).

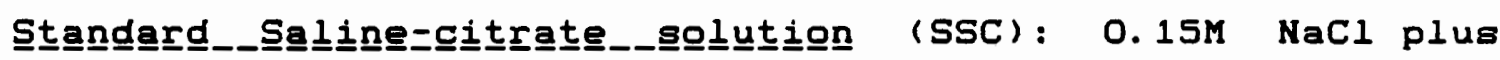
$0.015 M$ sodium citrate

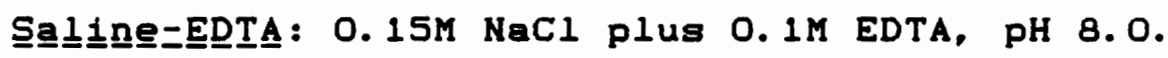
Aceetente=EEDTA: 3.OM sodium acetate plus 0.001M EDTA, PH 7.0. RNㅡaㅛㅌ﹎._I: Crystalline pancreatic RNase: $0.2 \%$ in $0.15 \mathrm{M} \mathrm{NaCl}$. The solution 18 heated at 80 degrees centigrade for 10 minutes. The heating is performed to inactivate any contaminating DNase.

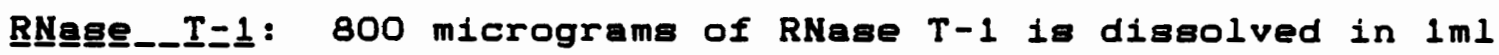
of $0.05 \mathrm{M} T$ Tris buffer $(\mathrm{pH} 7.80$ in the presence of $0.001 \mathrm{M}$ EDTA as an activator).

The cells were disrupted very easily, so it was not necessary to use lysozyme in this procedure. Organisms in 
fluid medium were centrifuged for $20 \mathrm{~min}$ e $10,000 \times \mathrm{G}$ to free the specimen from medium constituents, washed, and recentrifuged yielding approximately 6 grams of cells. The cells were then resuspended in $50 \mathrm{ml}$ Tris-SDS buffer with a glass rod. The SDS acts as a detergent, thus aiding in cell iysis. It also interacts with the DNases and supresses their action. An equal amount of phenol-buffer was added and the mixture was then shaken by hand in the cold for about twenty minutes. Slow speed centrifugation was used to separate the resulting emulsion into two layers. The upper portion (the aqueous layer) was clarified by centrifugation for ten minutes at $12,000 \mathrm{rpm}$. Two volumes of cold ethanol were then added in order to precipitate the nucleic acids. The precipitate was spun onto a glass rod and then dissolved in $20 \mathrm{ml}$ of $0.1 \times \mathrm{SSC}$. Then $2 m 1$ of $10 \times$ SSC was added.

The crude DNA solution was then combined with ribonuclease $I$ and ribonuclease $T-1$. This solution was incubated for thirty minutes at 37 degrees centigrade. After it ras cooled, an equal volume of phenol buffer was added and shaken in the cold. After this mixture was centrifuged, the aqueous layer was removed and centrifuged. Two volumes of ethanol were added to precipitate the DNA, and then washed by dipping successively in 70,80 , and $95 \%(v / v)$ ethanol. The DNA was dissolved in $20 \mathrm{ml}$ of $0.1 \times$ SSC, and $2 \mathrm{ml}$ of $10 \times \mathrm{SSC}$ were added. A few drops of chloroform were added for atorage in 
the cold.

Buoyant density was determined by centrifugation in a cesium chloride density gradient using a Beckman analytical ultracentrifuge. The DNA bage compogition was determined by the method of Schildkraut (34).

The following reagents were used:

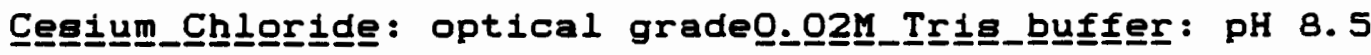

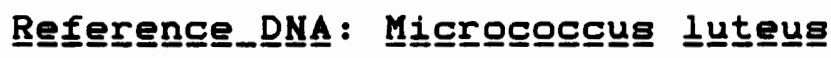

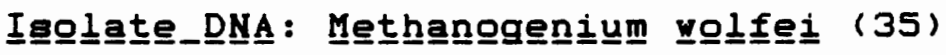

A stock solution of cesium chloride was prepared by dissolving 13 grams of cesium chloride into seven millititers of Tris buffer. Cells for the ultracentrifuge were assembled and tightened with the cell torque wrench at 20-30 seconds of 135 pounds torque. A solution was made containing $0.84 \mathrm{ml}$ of cesium chloride buffer, 40

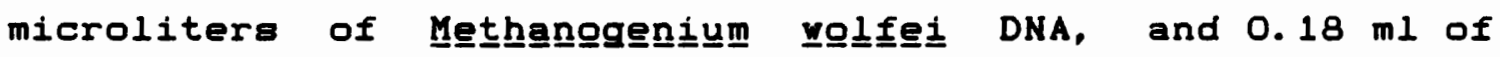
water. Solution was added via a blunt 22 -gauge needle on a one $m l$ syringe so that air space was occupying only $5 \%$ of the cell height. The final equillibrium photographs were taken after 20 hours at 44,700 rpm. Film was developed using Kodak D-11 developer.

\section{PREPARATION OF CRUDE EXTRACT}

The new isolate was mass cultured at 40 degrees centigrade in a 12 liter New Brunswick fermenter containing medium \#1. Hydrogen: carbon dioxide (80:20) was bubbled through the culture medium continuously. The organism was 
grown for one week with constant stirring. A Cepa-Schell continuous flow centrifuge was used to harvest the cells and yielded 40 grams of cells, wet weight. O.1M sodium phosphate buffer, $\mathrm{pH} 7.5$ was used to resuspend the cells $(2 \mathrm{ml} / \mathrm{g}$ of wet cells). This suspension was flushed with hydrogen and stored in the freezer. Cells were ruptured by passage through a french pressure cell at 20,000 lb/sq. in. The cell debris was then removed by centrifugation at 40,000 $\times 9$ for thirty minutes. The extract was stored at -20 degrees centigrade under a hydrogen atmosphere.

\section{ASSAY PROCEDURE FOR NADP REDUCTASE}

The assay was carried out according to the method of Eirich (20). The assay mixture contained $3.0 \mathrm{ml}$ of $0.1 \mathrm{M}$ sodium phosphate buffer (pH 7.5), $64 \mathrm{nmol}$ of reduced F-420, 1.04 micromoles of NADP and enzyme. The assay was performed at 40 degrees centigrade and was followed gpectrophotometrically at 350nm with a Turner spectrophotometer. The reaction was carried out in atoppered Baush and Lomb spectrophotometer tubes that had been flushed with hydrogen. One unit of activity is defined as the amount of enzyme required to reduce 1 micromole of NADP/min at $\mathrm{pH} 7.5$ and 40 degrees centigrade. Assays were performed under a hydrogen atmosphere. A similar assay procedure vas employed to quantitate F-420 in

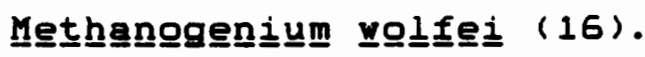


PURIFICATION AND PREPARATION OF REDUCED F-420

F-420 was purified by the method of Eirich et al. (22). The reduction of F-420 was carried out enzymatically by the use of a crude hydrogenase preparation. Two ml of F-420 ( $1 \mathrm{mg} / \mathrm{ml})$ in phosphate buffer was placed in a stoppered serum bottle $(10 \mathrm{ml})$. The solution was then flushed with hydrogen for five minutes and then incubated for five minutes at 60 degrees centigrade. 25 microliters of crude extract from M.-_thhermoauthotgrophingum was then added. The solution was mixed frequently and the reaction proceded for ten minutes. The serum bottle was subsequently pressurized to $20 \mathrm{lb} / \mathrm{sq}$. in. with hydrogen and allowed to continue incubation for five more minutes. The nearly colorless preparation was then placed in a boiling water bath for ten minutes in order to destroy enzymatic activity.

STANDARD ASSAYS FOR GROWTH AND METHANE PRODUCTION

Methane was analyzed by gas chromatography employing a Yarian gas chromatograph with a Poropak a column. Growth was measured by following the absorbance at $580 \mathrm{~nm}$ on a Turner colorimeter (one $\mathrm{cm}$ pathlength). 
RESULTS

ENRICHMENT AND ISOLATION

Isolation of the new strain was carried out by Eirich (35). Digesting sludge was collected from an anaerobic sludge digestor located at a sewage treatment plant in Hillsboro, Oregon. 1. Oml of sludge was added via syringe to a $125 \mathrm{ml}$ serum bottle containing $20 \mathrm{ml}$ of medium 1 (see TABLE 1) and pressurized (250kPa) with hydrogen: carbon dioxide (80:20). The culture was incubated without shaking for one week at 37 degrees centigrade. Methane was detected and highly irregular cocci: lamong many other morphological types of bacteria) vere observed. Upon examination with a fluorescence microscope, green fluorescing cocci were seen.

Isolated colonies were obtained from the enrichment by streaking plates of medium 1 ( $1.5 \%$ Noble agar) inside an anaerobic chamber (36). The plates were incubated for one week at 37 degrees centigrade under hydrogen: carbon dioxide (80:20) as described by Balch and Wolfe (14). Small, convex, circular colonies (0.5 to $1.0 \mathrm{~mm}$ in diameter) which were green-brown in color and tranglucent were obtained. The appropriate morphology was obaerved upon microscopic examination and cultures were further purified 
by the streak plate method.

Transfer of well-isolated colonies to liquid culture always resulted in contamination (ca. $5 \%$ ) by a rod shaped bacterium. To eliminate the contaminant, the liquid culture was serially diluted in medium 1. The highest dilution that showed growth and methane production was examined microscopically. Only the coccoid methanogen was observed; the rod-shaped contaminant was lost during serial dilution.

\section{MICROSCOPIC EXAMINATION}

The isolate normally appeared as single irregular cocci with a diameter of 1.5 to 2.0 micrometers (Figure 4A). Frequently highly irregular shapes were observed upon microgcopic examinataion (Figure 4B). No more than two or three cells were observed to be attached at anyone time. One to two polar flagella were routinely observed (Figure 5).

\section{OPTIMAL GROWTH CONDITIONS}

The usual growth medium contained $0.12 \mathrm{M}$ sodium ions. Optimal growth was obtained up to $0.2 M$ added sodium chloride with a small but repeatable dip at $0.1 \mathrm{M}$ (Figure 6). Growth was greatly inhibited at sodium chloride concentrations above $0.5 \mathrm{M}$.

The optimal growth temperature was 45 degrees centigrade (Figure 7). Minimal growth was observed below 


\section{F $\underline{\text { IGUERE__ }}$ 4.}

A. TYPICAL REGULAR TO IRREGULAR COCCI OF METHANOQGENIU⿴囗 WOLEFEI.

B. HIGHLY IRREGULAR SHAPE FREQUENTLY OBSERVED WITH THESE PLEOMORPHIC COCCI. BAR EQUALS 5 MICROMETERS. 


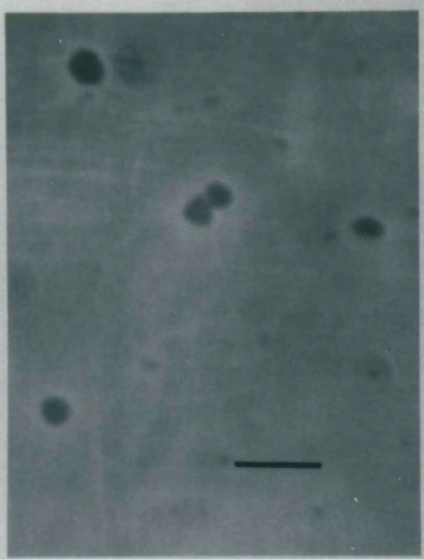

A

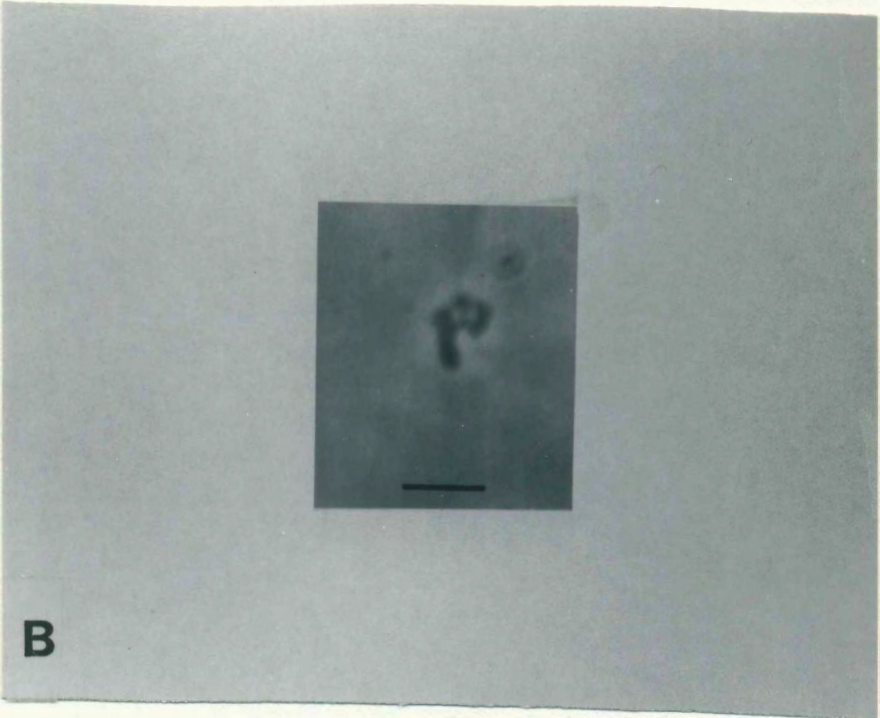

Figure 4 


\section{FII $\underline{\text { UU }} \underline{\text { REE_ }}$.}

GRAY'S FLAGELLA STAIN OF METHA

WOLFEEI. BAR EQUALS 5 MICROMETERS. 
Figure 5 
FIIGURE_.

EFFECT OF SODIUM CHLORIDE CONCENTRATION ON

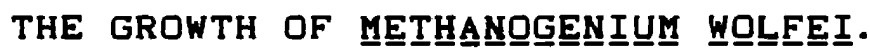
ADDITIONAL SODIUM IONS WERE AVAILABLE FROM OTHER SOURCES IN MEDIUM 1 AMOUNTING TO 5. 12M. ABSORBANCE WAS MEASURED AT $580 \mathrm{~nm}$ AFTER FOUR DAYS GROWTH AT 45 DEGREES CENTIGRADE IN MEDIUM 1. 


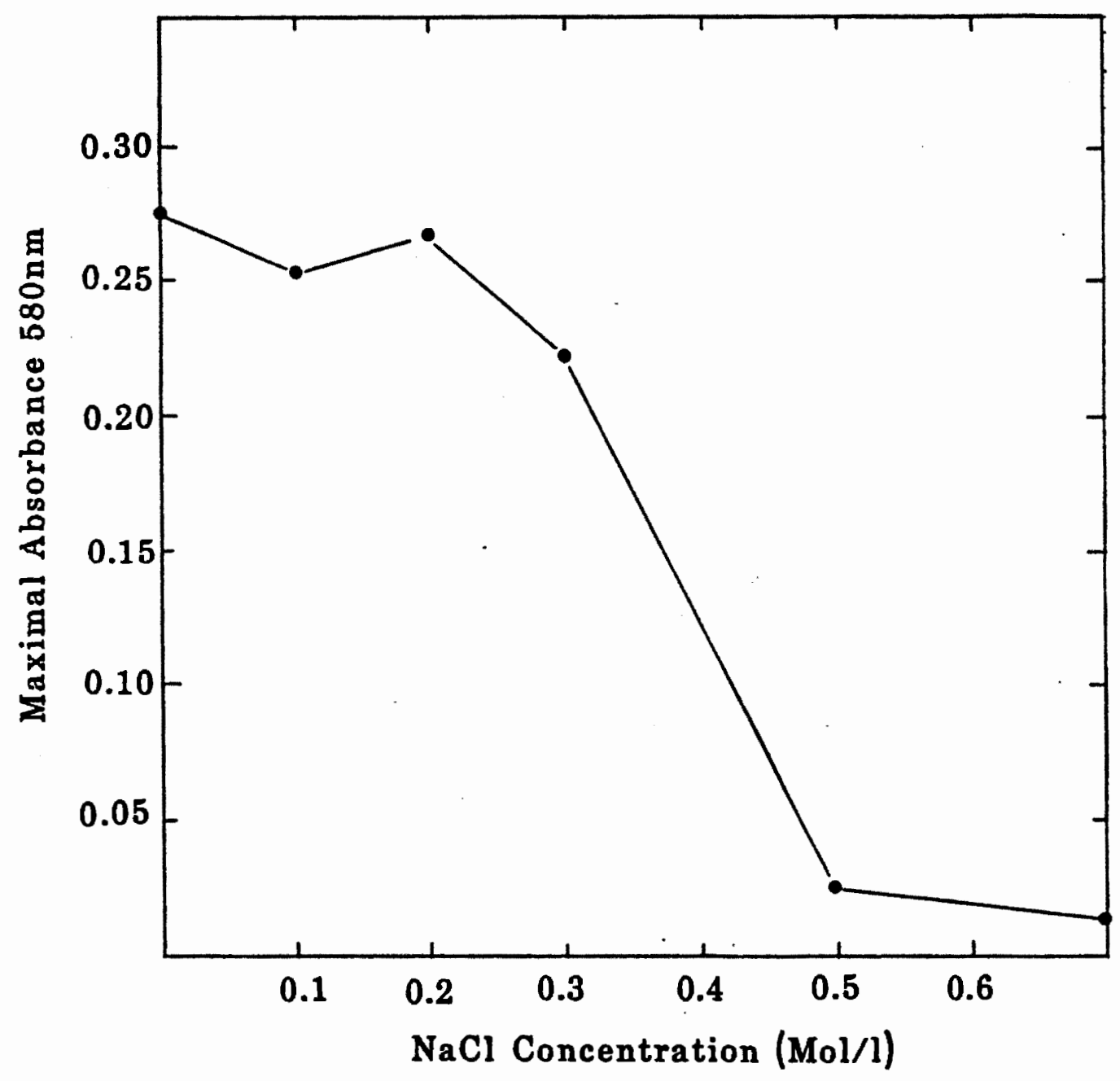

Figure 6 


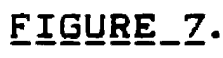

OPTIMAL TEMPERATURE FOR GROWTH OF MEITHANOGENIㅡ늠 WOLLEEI. 


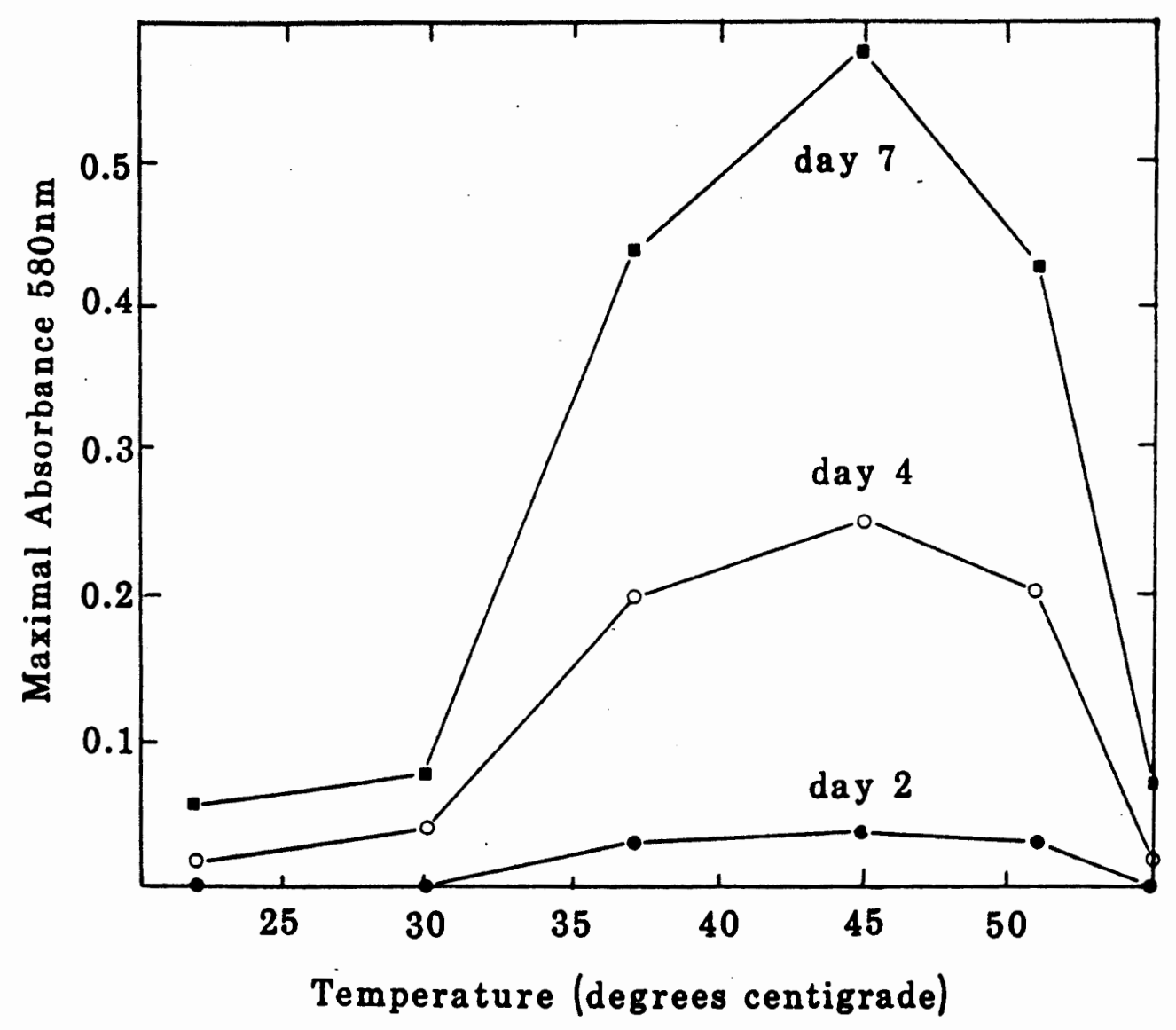

Figure 7 
30 degrees centigrade and above 55 degrees centigrade.

The optimal $\mathrm{pH}$ for growth was examined by varying the concentration of sodium bicarbonate that was added to the medium. A pH of 6.8 was found to be optimal (Figure 8 ).

The cells of the new isolate were extremely fragile. Moderate shaking (175RPM in a gyrating incubator) was sufficient to cause extensive lysis. Consequently, all cultures were incubated without mixing. A generation time of 16 hours was found for standing cultures grown in medium 1 at 45 degrees centigrade.

ORGANIC GROWTH REQUIREMENTS

The isolate was tested for growth under differing media compositions (TABLE III). The methanogen was able to grow well in a minimal medium plus added acetate and casamino acids (vitamin free). Tryptone or yeast extract, while not required, resulted in growth nearly equal to medium 1. Vitamins were neither stimulatory nor required. Through a series of experiments, we were able to determine that the casamino acids requirement could be replaced by a single amino acid, arginine (Figure 9 ). In order to determine individual amino acid requirements, amino acids were grouped according to their suspected biosynthetic families in four solutions. Growth was observed only in minimal media that had acetate and solution three added to it. This solution contained glutamic acid, arginine and proline. When each of these amino acids were added 


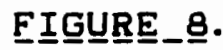

EFFECT OF PH ON GROWTH OF METHANOEGENIIUM WOLLFEI.

THE OPTIMUM PH FOR GROWTH WAS EXAMINED BY

VARYING THE CONCENTRATION OF SODIUM

BICARBONATE THAT WAS ADDED TO MEDIUM 1.

ABSORBANCE WAS MEASURED AT S80nm AFTER

FOUR DAYS GROWTH AT 45 DEGREES CENTIGRADE. 


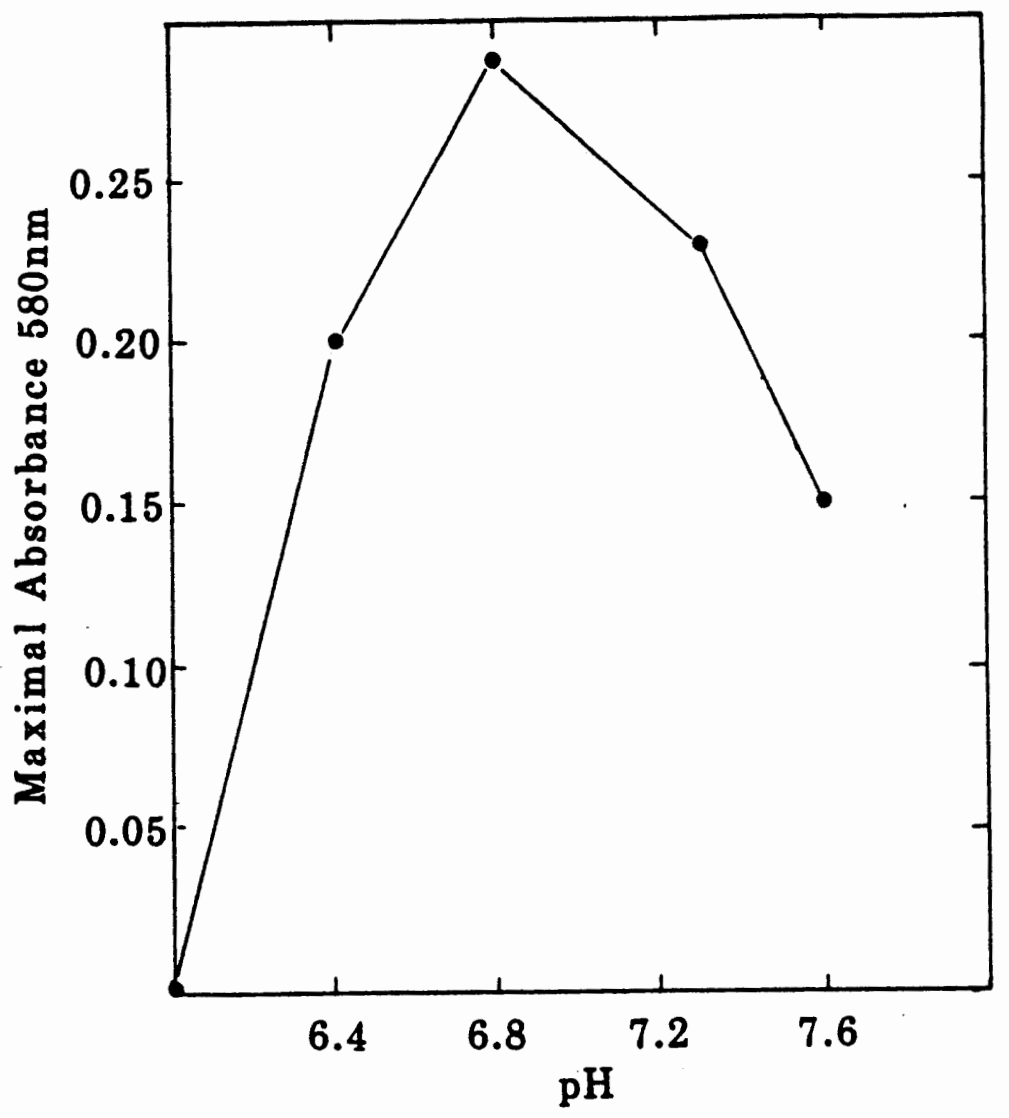

Figure 8 
TABLEE_III.

GROWTH REQUIREMENTS OF METHANOGENIUM WOLEEEI. 


\section{TABLE III}

Growth Requirements of Methanogentum wolfel

\begin{tabular}{|c|c|c|}
\hline Medium & Modificationa & $\begin{array}{l}\text { rbance } \\
580 \mathrm{~mm}\end{array}$ \\
\hline Medium $1^{b}$ & $=-$ & 0.22 \\
\hline \multirow[t]{7}{*}{ Medium $2^{b}$} & $-\infty$ & 0.00 \\
\hline & + acetate & .0 .00 \\
\hline & + casamino acids & 0.00 \\
\hline & + casamino acids, acetate & 0.10 \\
\hline & + Tryptone, acetate & 0.18 \\
\hline & + yeast extract, acetate & 0.18 \\
\hline & + yeast extract, Tryptone & 0.00 \\
\hline Medium 2c & + arginine, acetate & 0.125 \\
\hline
\end{tabular}

a All media were incubated under $\mathrm{H}_{2} / \mathrm{CO}_{2}(80 / 20)$ gas phase. The concentrations of acetate, Tryptone, and yeast extract were the same as in medium 1.

b Absorbance determined after four days of growth at $45^{\circ} \mathrm{C}$.

c Absorbance determined after seven days of growth at $45^{\circ} \mathrm{C}$. 
FIGURㅡㄹㅗ.

SCHEME FOR DETERMINATION OF AMINO ACID REQUIREMENTS. AMINO ACIDS WERE GROUPED BY THEIR SUSPECTED BIOSYNTHETIC PATHWAYS. MEDIUM THAT SUPPORTED GROWTH WAS FURTHER BROKEN DOWN TO INDIVIDUAL AMINO ACIDS. ARGININE WAS FOUND TO BE AN ESSENTIAL ADDITION TO SUPPORT GROWTH. 


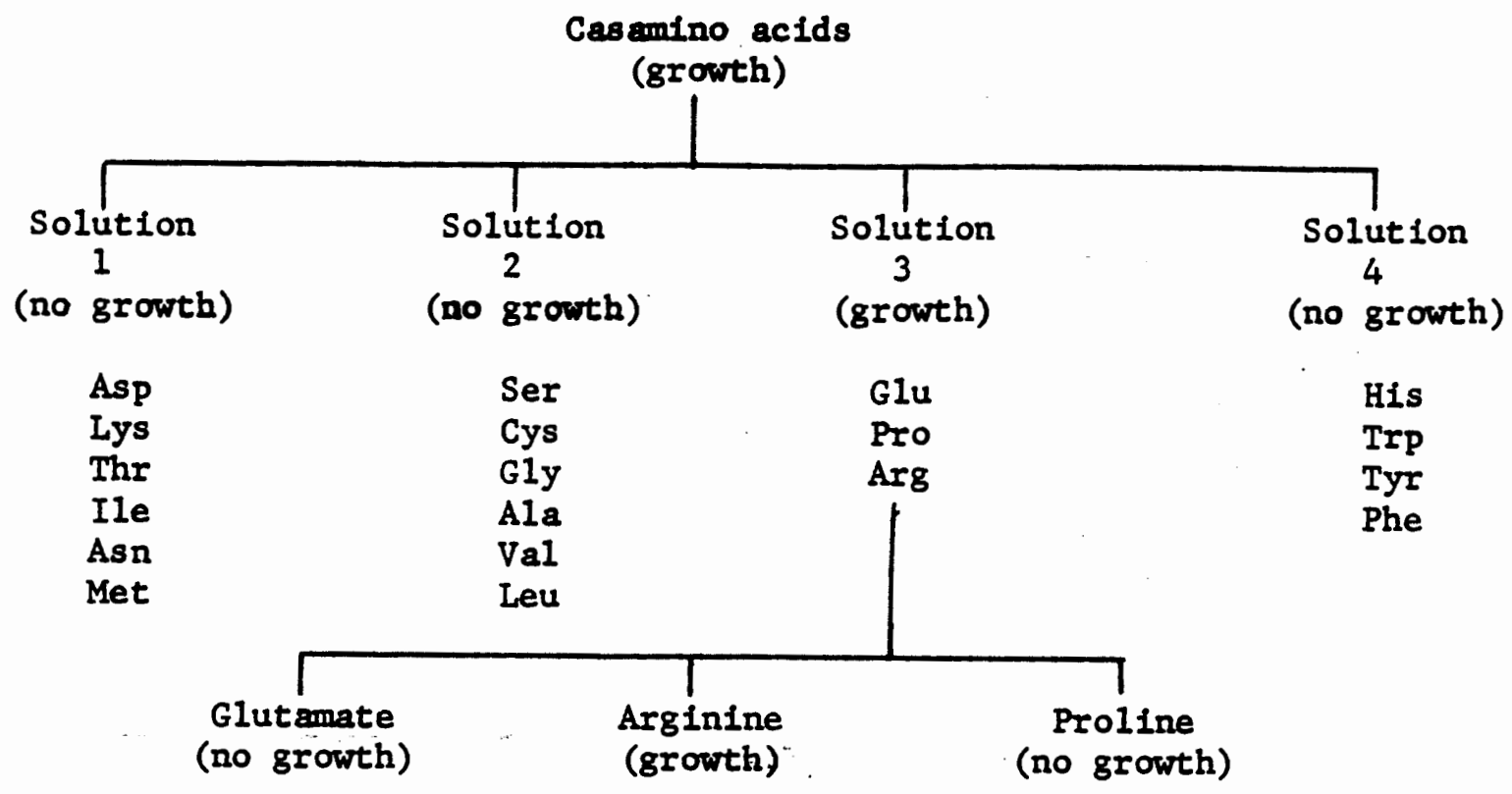

Figure 9 
seperately to minimal medium plus acetate, only the cultures with arginine exhibited growth. Further studies have shown that ornithine is capable of being substituted for arginine.

\section{GROWTH SUBSTRATES}

Either hydrogen plus carbon dioxide or formate served as substates for methane production, although cells grew more slowly and produced less methane when growing on formate. Neither methanol nor acetate supported growth or methanogenesis.

\section{DNA BASE COMPOSITION}

The DNA base composition of the isolate was determined by CsCl density ultracentrifugation to be 61.1

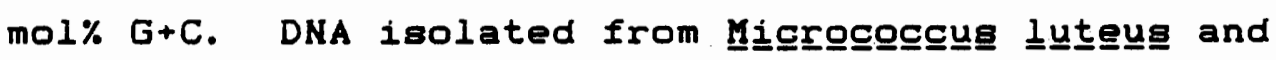

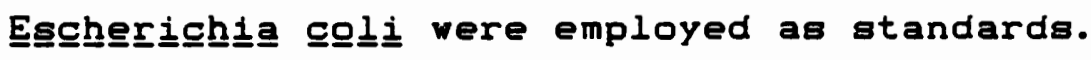

PRESENCE OF A NADP REDUCTASE AND F-420

An F-420-dependent NADP reductase was found to be present in Methangogeniuㅡ oㅡ로르. The enzyme is quite sensitive to oxygen at 4 degrees centigrade. Exposure to oxygen for 2 days at 4 degrees centigrade reuslted in a marked loss of $97 \%$ of original activity. Under a nitrogen atmosphere, no loss of activity was observed after 2 days at 4 degrees centigrade. The addition of cysteine to the phosphate buffer in which the enzyme was stored increased 
the stability of the enzyme when exposed to oxygen. Forty-seven percent of original activity was retained after 2 days exposure to oxygen at 4 degrees centigrade when cysteine was added to the buffer.

A temperature optimum of 45 degrees centigrade was determined for the enzyme. Minimal activity was observed below 20 degrees centigrade and above 60 degrees centigrade.

The cofactor $F-420$ was determined to be present in concentrations of $134 \mathrm{mg} / \mathrm{kg}$ wet weight of cells (16). 


\section{DISCUSSION}

A comparison of the properties of the new isolate with those presented for the genus, Methangogenimum (3), indicates that the new isolate should be classified in this genus. The cells are irregular cocci with a diameter of 1.5 micrometers. It also is similar to other members of this genus in that it has a high mol\% $G+C$ and lacks the ability to utilize acetate or methanol as substrates for methane production.

A comparison of the properties of the known species

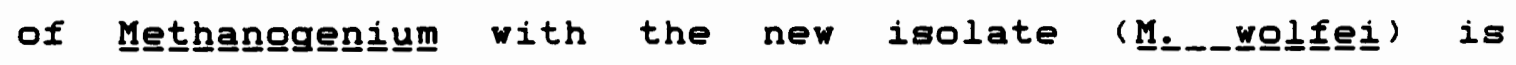
presented in TABLE IV. DNA base compositions vary from 52 to 61 mol\% G+C. Temperature optima for growth vary from 25 degrees centigrade to 55 degrees centigrade. All isolates

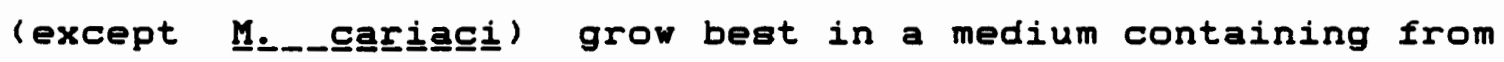
0.2 to $0.25 M$ sodium ions. All Methangnogeninum isolates except 므-_olenntㅌngyi are able to utilize formate as an

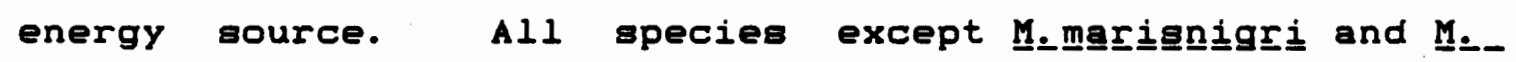

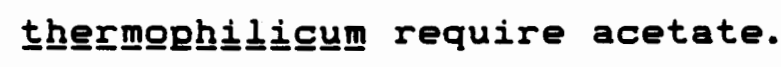

If one compares DNA base composition alone, the new isolate appears to be most closely related to M._marignigri and M._thermophilicum. It differs, however, from both of these species in its requirement for acetate and arginine (and lack of a requirement for Trypticase). The new 
TABLE_IIV.

A COMPARISON OF THE PROPERTIES OF THE KNOWN SPECIES OF METHANOEGENI느므. 


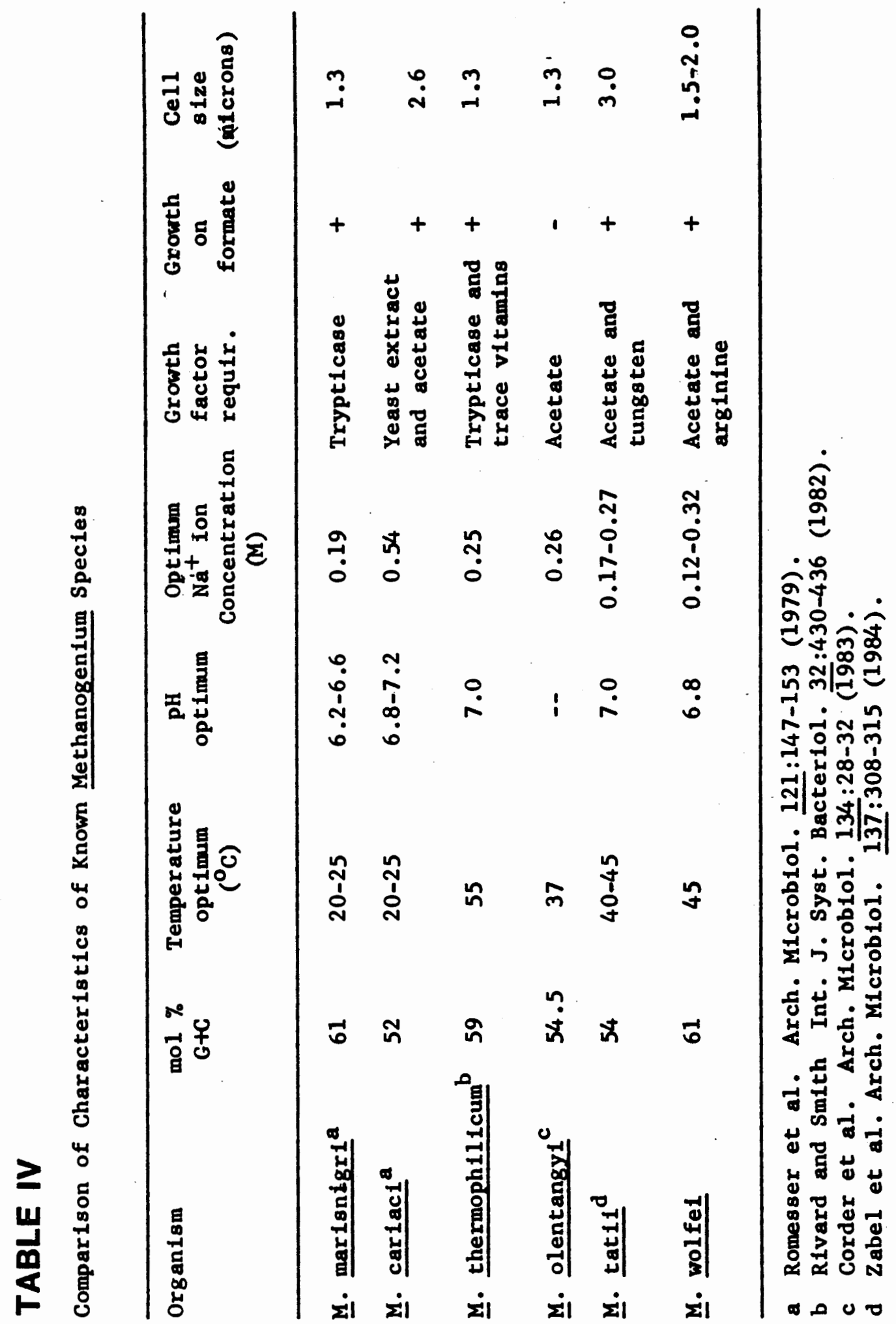


isolate also shows differences from the known species in its temperature optimum for growth and $\mathrm{pH}$ optimum for

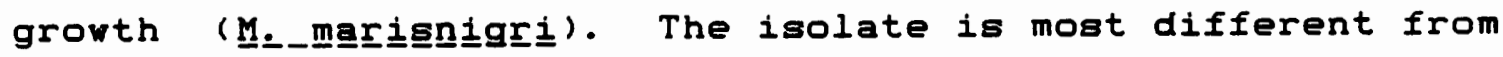
M.-_caraiagci, having only the requirement for acetate and $\mathrm{pH}$ optimum for growth as common properties.

If the new isolate is compared to the other

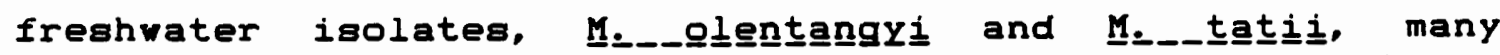
differences are also observed. There is a large difference in DNA base composition (ca. 7 mol\% G+C). There is a large

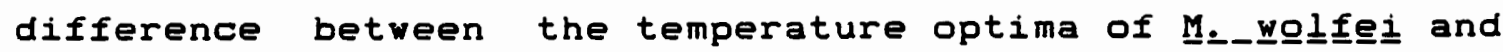

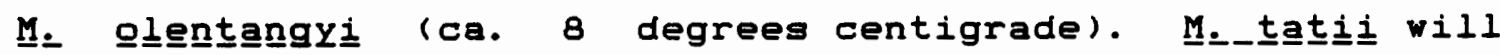
not grow at 50 degrees centigrade. M.-wolfeㅛ grows well at 51 degrees centigrade. The new isolate also differs from M._-_olentanangyi in its ability to grow on formate and differs from M.-tabtili in 1 ts requirement for casamino acids and the lack of a requirement for tungstate.

The similarities to other Methannoggeniun species prompts a recommendation for classification within the genus Methnangogeniiㅡ․ This isolate, however, has many characteristics unique to it. We submit, therefore, that these differences qualify this isolate to be accorded species status. 


\section{SUMMARY}

Description of Methanogenium wolfel, spec. nov.

Order: Methanomicrobiales

Family: Methanomicrobiaceae

Genus : Methanogenium

Species: Methanogenium wolfei, spec. nov., named in honor of $R$. S. Wolfe

Morphology: Regular to highly irregular Gram negative cocci. Average size 1.5-2.0 micrometers in diameter. 1 to 2 flagella per cell.

Colony Characteristics: Circular, convex, translucent, green-brown with a shiny surface.

Physiology: Either formate or hydrogen used as energy source. Neither methanol nor acetate alone will support growth or methanogenesis.

Nutrition: Acetate and arginine required for growth. Temperature Relationship: Optimum, $45^{\circ} \mathrm{C}$; $\operatorname{maximum}, 55^{\circ} \mathrm{C}$. $\mathrm{pH}$ relationship: Optimum, 6.8 . DNA Base Composition: $61 \mathrm{~mol} \% \mathrm{G}+\mathrm{C}$. Source: Sewage sludge 
REFERENCES CITED

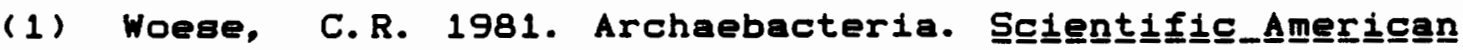
yolㅡ.-_24ㄴ. June: 98-122.

(2) Woese, C.R., L. Magrum, and G.Fox. 1978.

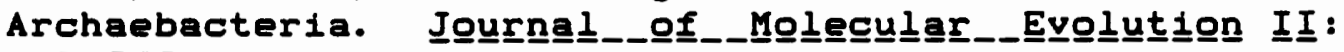
245-252.

(3) Balch, W.E., G.E. Fox, L. Magrum, C.R. Woese, and R.S. Wolfe. 1979. Methanogens: Reevaluation of a

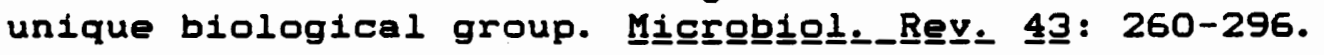

(4) Zeikus, J.G. and J.G. Ward. 1974. Methane formation in living trees: A microbial origin. Sciennce 1은 $1181-1183$.

(5) Mah, R.A., D.M. Ward, L. Bares1, and T.L. Glass.

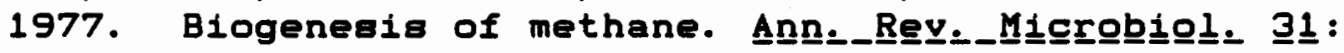
309-341.

(6) Klass, D.L. 1984. Methane from anaerobic fermentation. S토트므트 233: 1021-1028.

(7) Robinson, J.A. and J.M. Tiedje. 1984. Competion between sulfate-reducing and methanogenic bacteria for hydrogen under resting and groving conditions.

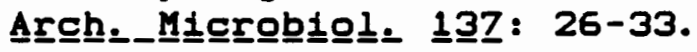

(8) Kasper, H.F. and K. Wuhrmann. 1978. Kinetic parameters and relative turnovers of gome important cartabolic reactions in digesting sludge. Appl.

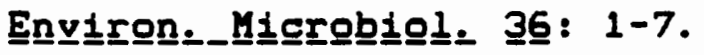

(9) Zinder, S.H. 1984. Microbiology of Anaerobic converaion of organic wastes to methane: Recent

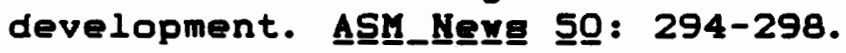

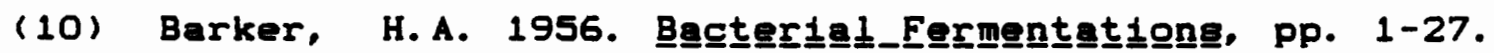
New YorkL: John Wiley \& Song.

(11) Smith, P.H. and R.E. Hungate. 1958. Isolation and

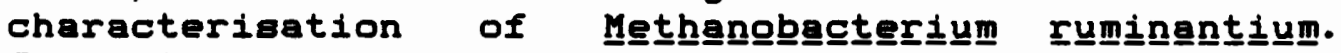

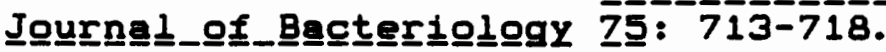

(12) Hungate, R.E. 1969. A roll tube method for cultivation of etrict anaerobes, pp. 117-132. In: 


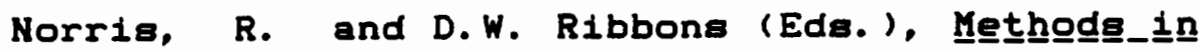

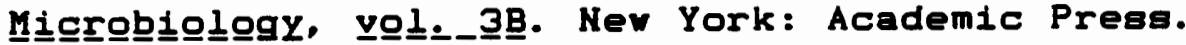

(13) Hungate, R.E., W. Smith, and R.T.J. Clarke. 1966. Suitability of butyl rubber stoppers for closing

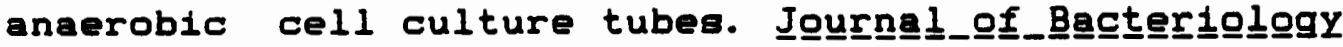
91: $908-909$.

(14) Balch, W.E. and R.S. Wolfe. 1976. New approach to the cultivation of methanogenic bacteria: 2-mercaptoethnasulfonic acid (HS-COM) -dependant growth of

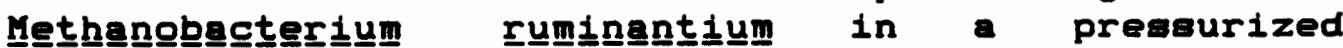

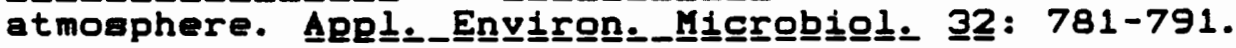

(15) Fox, G.E., L.J. Magrum, W.E. Balch, R.S. Wolfe, and C. R. Woese. 1977. Clagsification of methanogenic bacteria by 165 rRNA characterization. Proló-_Natl. A드르._S들. USA. 포: 4537-4541.

(16) Eirich, L.D., G.D., Vogels, and R.S. Wolfe. 1979. Distribution of Coenzyme F-420 and properties of $1 t s$

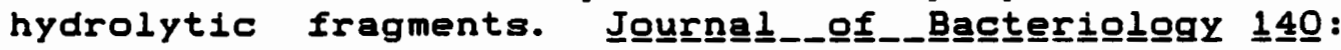
20-27.

(17) Ekiel, I., I.P. Smith, and G.D. Sprott. 1983.

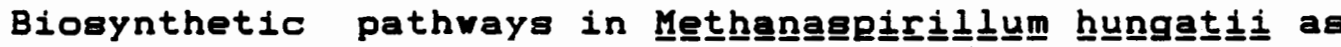
determined by carbon-13 nuclear magnetic resonnance.

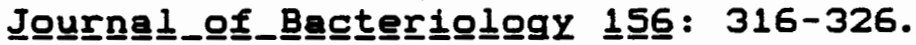

(18) Weimer. P.J. and J.G. Zeikus. 1979. Acetate

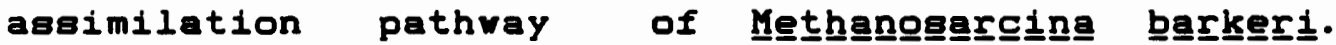

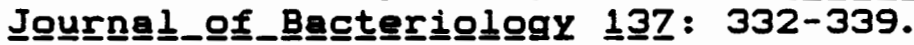

(19) Zeikus, J.G., G. Fuchs, W. Kenealy, and R.K. Thauer. 1977. Oxidoreductasea involved in cell carbon

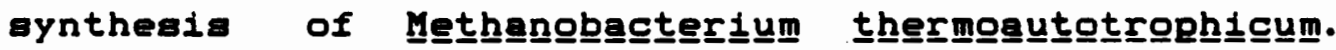

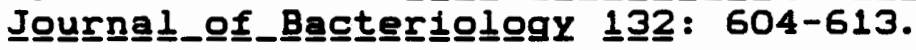

(20) Eirich, L.D. and R.S. Dugger. 1984. Purification and properties of an F-420 -dependant NADP reductase from

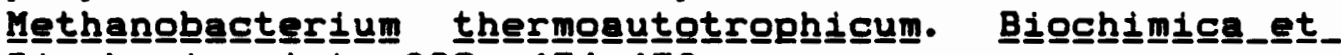

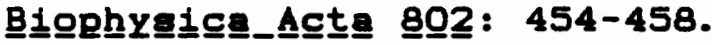

(21) Cheegeman, P., A. Tomm-Wood, and R. S., Wolfe. 1972. Isolation and properties of a fluorescent compound,

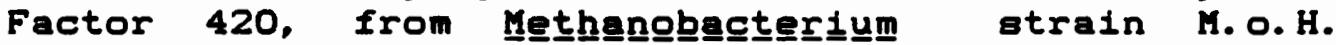

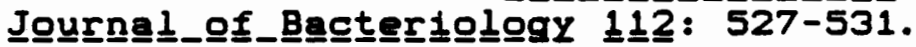

(22) Eirich, L.D., G. D. Vogele, and R.S. Wolfe. 1978. Proposed atructure for coenzyme F-420 from

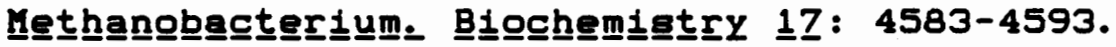

(23) Tzeng, S.F.. R.S. Wolfe, and M.P. Bryant. 1975. Factor 420 -dependant pyridine nuucleotide-linked

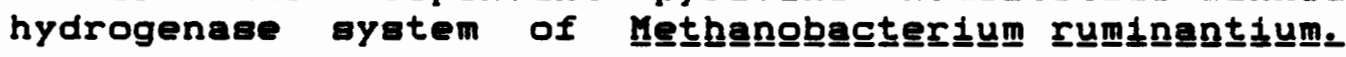




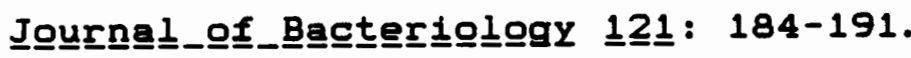

(24) Kandler, 0 . and H. Hippe. 1977. Lack of peptidoglycan in the cell walla of Methangogarcinge barkeseri. Archhiveg

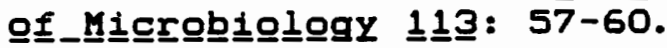

(25) Huser, B.A., K. Wuhrman, and A.J.B. Zehnder. 1982.

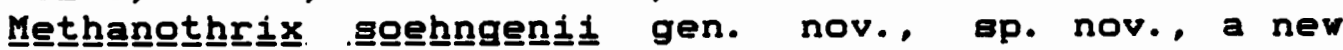
acetotrophic non-hydrogen oxidizing methane

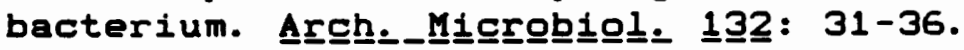

(26) Konig. H., and K.0. Stetter. 1982. Isolation and

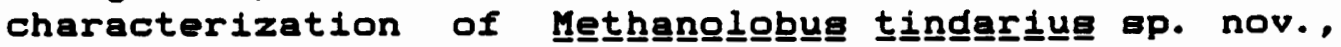
a coccoid methanogen growing oniy on methanol and

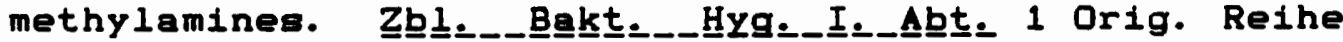
C. 3: 478-490.

(27) Sowers, K.R., and J.G. Ferry. 1983. Isolation and characterization of a methylotrophic marine

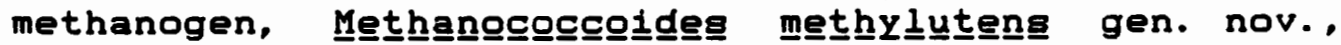

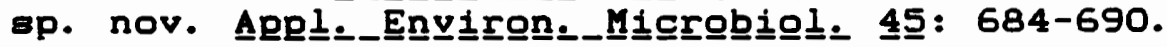

(28) Wildgruber, G., M. Thomm, H. Konig, K. Ober, T.

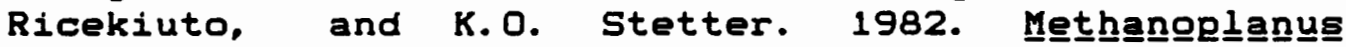
límnićcola, a plate-shaped methanogen representing a

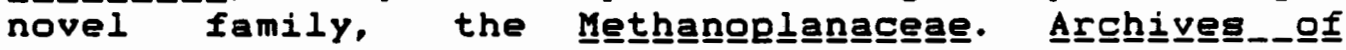
M11도으므보으으gy 132 : $31-36$.

(29) Paynter, M.J.B. and R.E. Hungate. 1968.

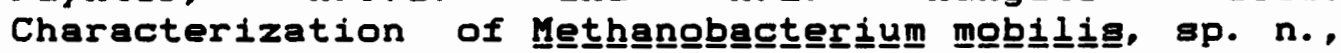
isolated from the bovine rumen. Journea‥-_of Bacctereio이의y 95: 1943-1951.

(30) Ferry, J.G., P.H. Smith, and R.S. Wolfe. 1974.

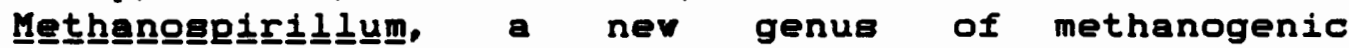

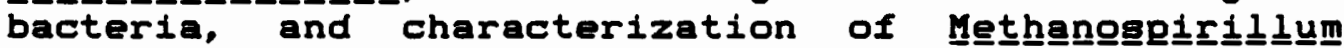

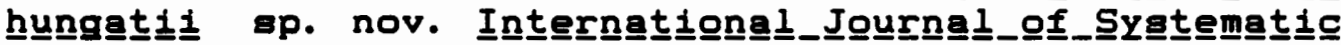

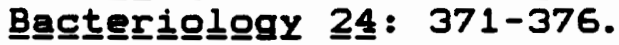

(31) Romegser, J.A., R.S. Wolfe, F. Mayer, E. Spiegs, and

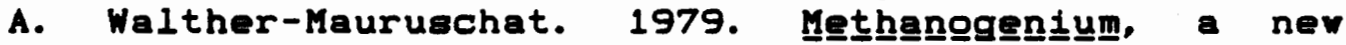
genus of marine methanogenic bacteria, and characterization of Methangogeníum car

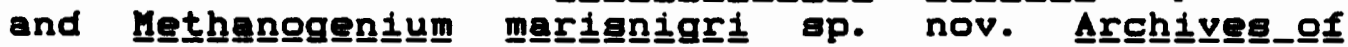

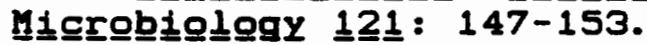

(32) Gerhardt, P., R.G.E. Murray, R.W. Costilow, E.W. Nester, W.A. Wood, N.R. Krieg, and G. B. Phillips.

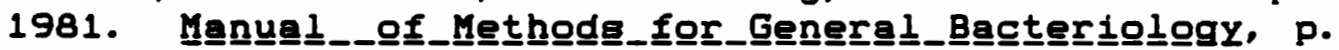
29-30. American Society of Microbiology, Washington, D.C.

(33) Saito, H. and K. Miura. 1963. Preparation of transforming deoxyribonucleic acid by phenol

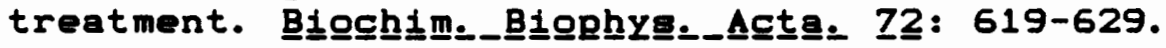


(34) Schildkraut, C.L., J. Marmur, and P. Doty. 1962. Determination of base composition of deoxyribonucleic

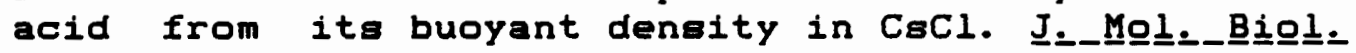
4. $430-443$.

(35) Moore, T.B. and L.D. Eirich. 1985. Isolation and characterization of a new freshwater methanogen,

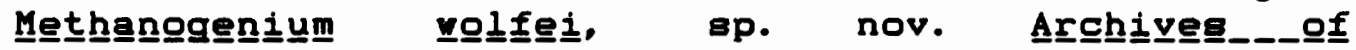

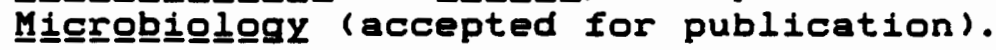

(36) Arank1, A. and R. Freter. 1972. Uae of anaerobic glove boxes for cultivation of atrictly anaerobic

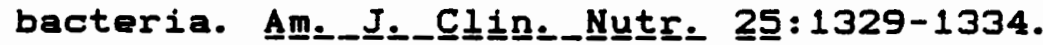

